\title{
New Insights into Pre-to-Post Ediacaran Zircon Fingerprinting of the Mamfe PanAfrican Basement, SW Cameroon: A Possible Link with Rocks in SE Nigeria and the Borborema Province of NE Brazil
}

\author{
Nguo Sylvestre Kanouo ${ }^{1, *}$, David Richard Lentz ${ }^{2}{ }^{(1)}$, Khin Zaw ${ }^{3}$, Charles Makoundi ${ }^{3}$, \\ Emmanuel Afanga Archelaus Basua ${ }^{4}$, Rose Fouateu Yongué ${ }^{5}$ and Emmanuel Njonfang ${ }^{6}$
}

1 Mineral Exploration and Ore Genesis Unit, Department of Mining Engineering and Mineral Processing, Faculty of Mines and Petroleum Industries, University of Maroua, Kaélé 08, Cameroon

2 Department of Earth Sciences, University of New Brunswick, Fredericton, NB E3B 5A3, Canada; davidrlentz@gmail.com

3 CODES Centre of Ore Deposits and Earth Sciences, University of Tasmania, Hobart Tasmania 7001, Australia; Khinzaw.nilar@gmail.com (K.Z.); c.makoundi@utas.edu.au (C.M.)

4 State Key Laboratory of Biogeology and Environmental Geology, China University of Geosciences, Wuhan 430074, China; basfanga@yahoo.com

check for updates

Citation: Kanouo, N.S.; Lentz, D.R.; Zaw, K.; Makoundi, C.; Basua, E.A.A.; Yongué, R.F.; Njonfang, E. New Insights into Pre-to-Post Ediacaran Zircon Fingerprinting of the Mamfe PanAfrican Basement, SW Cameroon: A Possible Link with Rocks in SE Nigeria and the Borborema Province of NE Brazil. Minerals 2021, 11, 943. https://doi.org/10.3390/min11090943

Academic Editors: Victoria

B. Ershova, Artem V. Moiseev and Andrey K. Khudoley

Received: 18 June 2021

Accepted: 21 August 2021

Published: 30 August 2021

Publisher's Note: MDPI stays neutral with regard to jurisdictional claims in published maps and institutional affiliations.

Copyright: () 2021 by the authors. Licensee MDPI, Basel, Switzerland. This article is an open access article distributed under the terms and conditions of the Creative Commons Attribution (CC BY) license (https:// creativecommons.org/licenses/by/ $4.0 /)$.
5 Department of Earth Sciences, University of Yaoundé I, Yaoundé 812, Cameroon; rfyongue@yahoo.fr

6 Higher Teachers Training School, University of Yaoundé I, Yaoundé 812, Cameroon; enjonfang@yahoo.fr

* Correspondence: sylvestrekanouo@yahoo.fr; Tel.: +237-678966240

Abstract: The pre- to post-Late Neoproterozoic geological histories in the south to southwestern part of Mamfe Basin (SW Cameroon) were reported following analysis of the zircon crystals from their host rocks. A genetic model was developed for the zircon host rocks' formation conditions, and the registered post-emplacement events were presented. The obtained ages were correlated with the data available for rocks in the Cameroon Mobile Belt, SE Nigeria, and the Borborema Province of NE Brazil. Separated zircons from Araru black to whitish gneiss, Araru whitish-grey gneiss, and Mboifong migmatite were analyzed for their morphology and texture U-Th-Pb composition, and $\mathrm{U}-\mathrm{Pb}$ ages. Published $\mathrm{U}-\mathrm{Pb}$ zircon ages for Otu granitic pegmatite, Babi mica schist, and Nkogho I-type anatectic granite were updated. Zircon ages in Araru black to whitish gneiss; Araru whitish-grey, Mboifong migmatite, Babi mica schist, Nkogho I-type anatectic granite, and Otu granitic pegmatite date the Eburnean tectono-magmatic/metamorphic event in Cameroon and SE Nigeria. The Late Paleoproterozoic to Early Mesoproterozoic ages record extensional (continental rift) settings and anorogenic magmatism in the Borborema Province in the NE of Brazil. These ages date collisional phases between the São Francisco-Congo and West African cratons and the Saharan metacraton with metamorphism and magmatism in Cameroon. They also date the Kibarian tectono-magmatic/metamorphism and PanAfrican tectono-magmatic/metamorphism in SE Nigeria. The Late Paleoproterozoic to Early Mesoproterozoic ages date the Cariris Velhos orogeny in the Borborema Province in NE Brazil, with Early Tonian crustal rifting, magmatism, and metamorphism and the collisional phase of the Brasiliano orogeny with syn-collisional plutons and extensive shear zoning and post-collisional granite intrusions.

Keywords: Cameroon PanAfrican Basement; Mamfe Basin; SE of Nigeria; NE of Brazil; U-Pb zircon

\section{Introduction}

Zircon geochronology is one of the key methods used to determine the ages of geological processes, including magmatic crystallization, different post-crystallization episodes [1-7], fingerprinted metamorphism [2,8-14], and hydrothermal activity [15-18]. It also helps for provenance studies and paleogeographic reconstitution (e.g., [19-29]). Coupled with zircon morphology-textural analyses and U-Th composition helps to better 
understand geological processes $[3,5,6,19,30-33]$. The two above features are useful in discriminating metamorphic, hydrothermal, and magmatic crystallized zircons in a host rock $[3,5,11,19,31,34]$. Metamorphic zircons, in particular, show distinctive external morphology (sign of resorption or overgrowth, rounded, ovoid, or soccer-ball shape) $[3,5,19,31]$ and internal textures (growth zones, preserved igneous cores, recrystallized domains, and domains showing other types of structural reorganization) $[3,19,30,31]$. The identification and study of these specific features can help us understand the zircon crystallization, growth conditions, and history; additionally, these features help reconstitute the different metamorphic grades and related episodes of growth [19,31]. Migmatites, granulites, gneisses, eclogites, and mica schists are examples of rocks capable of hosting metamorphic zircon morphologies, textures, and distinctive Th/U ratios [3,5,11,12,19,31,33,35]. They can also host syngenetic and/or inherited magmatic zircon features useful for their characterization, petrogenetic, and tectonic reconstitutions [3,5,19,30,31].

The basement rocks (migmatites, mica schists, gneisses, granites, anactetites, and syenites) in the Mamfe Sedimentary Basin in the southwest region of Cameroon are part of the PanAfrican Cameroon Mobile Belt (Figure 1) [5,6,36-38], a Neoproterozoic to early Palaeozoic zone formed from a combination of tectonic, magmatic, and metamorphic activities (e.g., [39,40]). Some rocks in this PanAfrican Cameroon Mobile Belt show similarities with those in SE Nigeria and NE Brazil [41-43]. Granites and mica schists in the Mamfe Sedimentary Basin host zircon crystals, which have been characterized. The obtained characterizations have been used to understand the formation of those rocks $[5,6,38]$. Otu granitic pegmatite in the western part of the basin was formed during Ediacaran to Cambrian times from a progressive cooling crustal magma [5]. The arc-like Nkogho I-type granitoid in the SW of the Mamfe Basin was crystallized from granitic magma during Cryogenian to Ediacaran times and was later affected by post-Ediacaran Cambrian to Albian magmatic events with the later age probably dating the opening of the basin [6]. Mica schist outcrops found in Babi (SW of the Mamfe Basin) enclose Paleoproterozoic to Mesoproterozoic magmatic zircon inheritances and Cryogenian to Ediacaran syngenetic magmatic and metamorphic zircons with the later ages dating the formation of this mica schist during the PanAfrican tectono-magmatic/metamorphic events [5]. Detailed information on migmatites, gneisses, and anactectites are limited, except those of their petrography in [36,37] and from reconnaissance mapping [38]. In this study, we: (1) update available geochronological data for basement rocks in the Mamfe Basin (SW Cameroon), the Borborema Province (NE Brazil) and SE Nigeria, as ages for some rocks in these two zones show closeness with those in the Cameroon Mobile Belt (see [41-43]); and (2) present zircon morphology and textural features, U-Th abundance, $\mathrm{Th} / \mathrm{U}$ ratios, $\mathrm{U}-\mathrm{Pb}$ ages for gneisses cropping in Araru, and migmatite in Mbiofong (SW of the Mamfe Basin). These data are used to: (1) determine zircon crystallization and/or growth history; (2) elucidate zircon's host rock formation and fingerprinted post-formation events; and (3) compare obtained ages to those of rocks found in the southwestern part of the Cameroon Mobile Belt, SE Nigeria, and the Borborema Province (NE Brazil) for an approach to regional correlation.

\section{Overview on the Geochronology of the PanAfrican Cameroon Mobile Belt, Borborema Province NE of Brazil and SE of Nigeria}

\subsection{The PanAfrican Cameroon Mobile Belt}

The Cameroon Mobile Zone or Central African Fold Belt is a megatectonic structure underlying Cameroon, Chad, and the Central African Republic between the Congo craton to the south and the Nigerian shield to the north [44]. It was formed during the Neoproterozoic, from the collision between the Saharan metacraton and the Congo craton $[45,46]$. The Cameroon Mobile Belt between the Congo craton in the south and the Nigerian basement in the northwest consists of Neoproterozoic supracrustal assemblages and variously deformed granitoids with tectonically interlayered wedges of Paleoproterozoic basements [39]. The southern part displays medium-to-high-grade Neoproterozoic rocks, including $620 \mathrm{Ma}$ granulites, which are interpreted to have formed in a continental collision zone and were thrust over the Congo craton, whereas the central and northern parts expose a giant shear 
belt characterized by thrust and shear zones, which have been correlated with similar structures in northeastern Brazil and which are late collisional features [39]. Geochronology of the oldest rocks within the Cameroon Mobile Zone including the Paleoproterozoic gneissic basement, Mesoproterozoic to Neoproterozoic schists, and gneisses of Poli, Yaoundé, and Lom, as well as PanAfrican granitoids whose ages range from the early stage of the deformation (orthogneisses) to the late uplift stages of the belts [47], were presented [48]. The ages of some Paleoproterozoic to Early Cambrian rocks found within the Cameroon Mobile Belt are presented in Table 1.

Table 1. Ages of some Paleoproterozoic to Early Cambrian rocks found within the Cameroon mobile belt.

\begin{tabular}{|c|c|c|c|}
\hline Paleoproterozoic (2118 to $1617 \mathrm{Ma}$ ) & $\begin{array}{l}\text { Early to Mid Neoproterozoic } \\
\text { (920 to } 630 \mathrm{Ma})\end{array}$ & Late Neoproterozoic (620 to $575 \mathrm{Ma}$ ) & $\begin{array}{c}\text { Late Ediacaran to Early Cambrian } \\
\text { Ages (569 to } 510 \mathrm{Ma} \text { ) }\end{array}$ \\
\hline $\begin{array}{l}\text { (1) } 2.1 \text { Ga garnet amphibolites and } \\
\text { tonalitic to trondhjemitic gneisses [49] }\end{array}$ & $\begin{array}{c}\text { (1) } 830 \text { to } 700 \text { Ma intrusions and } \\
\text { low-to high-grade schists and } \\
\text { gneisses of Poli-Maroua } \\
\text { Group [51] }\end{array}$ & (1) $620 \pm 10$ Ma granulite in Yaoundé [53] & $\begin{array}{c}569 \pm 12 \text { to } 558 \pm 24 \text { Ma and } 533 \pm 12 \\
\text { to } 510 \pm 25 \text { Ma for Nkambe } \\
\text { granitoids }[58,59]\end{array}$ \\
\hline \multirow{5}{*}{$\begin{array}{l}\text { (2) } 2.06 \text { Ga Ititin metabasite found in } \\
\text { the western border of the } \\
\text { Adamawa-Yade domain [49] } \\
\text { (3) } 1617 \pm 16 \text { Ma Bafia Group } \\
\text { metasediments [50] }\end{array}$} & $\begin{array}{l}\text { (2) } 668 \pm 11 \text { Ma Mokong } \\
\text { granite [51] }\end{array}$ & (2) 618 magmatic rock of Tonga [54] & \\
\hline & $\begin{array}{l}\text { (3) } 645-630 \text { Ma Rey Bouba } \\
\text { Greenstone Belt [48] }\end{array}$ & $\begin{array}{c}\text { (3) } 601 \text { to } 586 \text { Ma Mamb meta-gabbros and } \\
\text { meta-hornblendites [55] }\end{array}$ & \\
\hline & $\begin{array}{l}\text { (4) } 630 \text { to } 547 \text { high-K I-type } \\
\text { granites in Batié [52] }\end{array}$ & $\begin{array}{c}\text { (4) } 600 \mathrm{Ma} \text { Ngondo granites [56] and Bafia } \\
\text { monzodiorite [50] }\end{array}$ & \\
\hline & & $\begin{array}{c}\text { (5) } 578 \text { Ma Dschang high-K I-type biotite } \\
\text { granite [57] }\end{array}$ & \\
\hline & & $\begin{array}{l}\text { (6) } 563 \text { Ma Dschang high-K I-type } \\
\text { magnetite granite [57] }\end{array}$ & \\
\hline
\end{tabular}

\subsection{The Borborema Province PanAfrican NE Brazil}

The Borborema Province, in NE Brazil, is geologically a Neoproterozoic (620-570 Ma) tectonic-magmatic/metamorphic megastructure formed from interference between two collisions [60]. Documented in [61], the Borborema Province was built in the Neoproterozoic by agglutination of allochthonous lithospheric fragments during the Cariris Velhos ( 1000-920 Ma) and Brasiliano ( 625-510 Ma) orogenies. The oldest basement rocks are the Archean to Paleoproterozoic aged (3.7-2.0 Ga) TTG-type orthogneisses and metasedimentary rocks, such as paragneisses and schists, mafic to ultramafic rocks, and alkaline intrusions [62-66]. Other old basement rocks include the Late Paleoproterozoic to Mesoproterozoic aged rocks of the metavolcano-sedimentary units (developed in extensional continental rift settings and aged at $1.8 \mathrm{Ga}$ [67]) and the Late Paleoproterozoic and Mesoproterozoic anorogenic magmatism (in the transversal zone, aged ca. 1.7-1.5 Ga, with locally high representation) [68,69].

Early Tonian magmatism and sedimentation (1000-920 Ma), as well as components of complete plate tectonic cycles during the Neoproterozoic (ca. 900-540 Ma), were also found [65,70-73]. Early Tonian to Ediacaran aged basement rocks include (1) 900-800 Ma crustal extension mafic to ultramafic intrusions ( 900 Ma [74]), continental-rift basic volcanic rocks ( 882 Ma [75]), and A-type orthogneisses ( 869 Ma [76]); (2) 820-650 Ma continental drift following the Tonian rifting that culminated with oceanic crust development [75] and separation of the Borborema lithospheric blocks from the São Francisco-Congo paleocontinent, and the development of rift/passive margin units [73]; (3) 650-620 Ma subducted and continental arc phases enclosing syn-orogenic, greywacke-rich units with intermediate to felsic volcanic and volcaniclastic intercalations [75]; and (4) 620-590 Ma collisional phase of the Brasiliano orogeny associated with crustal anatexis generated syn-collisional plutons $[75,77,78]$. Extensive shear zone networks were developed towards the end of the Brasilia orogeny, which are spatially related to post-collisional granite intrusions of $\sim 590$ to $510 \mathrm{Ma}$ (e.g., [79-82]). The other post-collisional and post-Ediacaran episodes are the $460 \mathrm{Ma}$ felsic dykes cross-cut by faults parallel to the main trend of the Transbrasiliano shear zone [83]. These shear zones commonly border Cretaceous intraplate sedimentary 
basins formed during ductile-to-brittle deformed phases characterized by normal faults overprinting mylonitic foliations [82]. Calcite slickenfibre-bearing faults that yielded a $\mathrm{U}-\mathrm{Pb}$ age of $135 \pm 4.7 \mathrm{Ma}$ (from dating filled-rock sampled zircons) can be associated with the opening of the South Atlantic Ocean [82].

\subsection{The PanAfrican SE of Nigeria}

The PanAfrican basement, or Nigeria Basement Complex, is believed to be a reworked older crust (probably Liberian in age), which has been further reworked by later orogenies like the Eburnean (2000 $\pm 200 \mathrm{Ma})$ and PanAfrican (600 $\pm 150 \mathrm{Ma})$ [84]. The orogenies likely resulted in the addition of the granitoids and schist belts [84]. Kibaran (1300-1100 Ma) sedimentation and deformation were evidenced within the rocks of the Nigeria Basement Complex [85]. The Kibarian was followed by ages ranging from 900-450 Ma representing the imprint of the PanAfrican orogenic events (around $600 \pm 70 \mathrm{Ma}$, [86]) that gave rise to migmatite, gneisses, and older granite intrusions [84]. The PanAfrican basements in SE Nigeria are composed of gneisses, phyllites, schists, amphibolites migmatites, and granites [87-89]. Basement rocks in this complex were invaded by numerous intrusive bodies ranging from massive to thin dyke-like bodies [88]. These intrusive rocks include granites, dolerites, pegmatites, syenites, diorites, granodiorites, and charnockites [89]. The metamorphic basement rocks in the Oban area of SE Nigeria, which underwent polymetamorphism, with the grade ranging from medium greenschist facies in phyllites and schists to uppermost amphibolite facies in the kyanite-sillimanite schists, garnet sillimanite schists, and migmatic gneisses [90]. Schists and gneisses, which crop out in Oban, range in age from 527 to $680 \mathrm{Ma}$, whereas a Rb-Sr isochron age for banded amphibolites is $784 \pm 13 \mathrm{Ma}$, and the zircon evaporation age for the banded gneiss is $1931 \pm 2$ Ma [91,92].

\section{Local Geological Setting}

The Mamfe Sedimentary Basin (now Mamfe Basin; Figures 1 and 2) is Cretaceous in age [93-95]. It is a tectono-sedimentary structure formed during the opening of the southern part of the Atlantic Ocean $[37,96]$. This basin is historically and genetically linked to the Benue Trough (in southeast Nigeria) [37,97], a linear mega-depression filled with up to $6500 \mathrm{~m}$ of lithified marine and continental sediments [98,99] ranging in age from Mid Albian to Maastrichtian [98,100]. It is a NW-SE segment of the NE-SW trending Benue Trough, which started to form during the opening of the Gondwana supercontinent in the Triassic [37]. The similarity in the mode of tectonic evolution between the Mamfe Basin and the Benue Trough is supported by their presence of both rifts and fold axes that are parallel to their respective basin axes [97].

The rift propagated along existing lines of weakness and broadened during early Jurassic times [37]. It was suggested [102] that rifting in the Mamfe Basin aborted in the Upper Albian to Lower Cenomanian due to the sub-crustal contraction and compression that led to the westward displacement of its depositional axis. Spreading ceased in the mid Jurassic, and as the lithosphere cooled, the shallow depression deepened [103]. Indeed, rifting that formed the Mamfe Basin is thought to have been accompanied by rapid tectonic subsidence that was in response to thermal recovery of the lithosphere following the thermal disturbance that led to the stretching and thinning of the crust beneath the basin [97]. Sedimentation in the Mamfe Basin started in the Albian [37], as Gondwana started to break up, during the Early Cretaceous [104]. Several small NW-trending anticlines are reported at the eastern end of the Mamfe Basin [105]. 


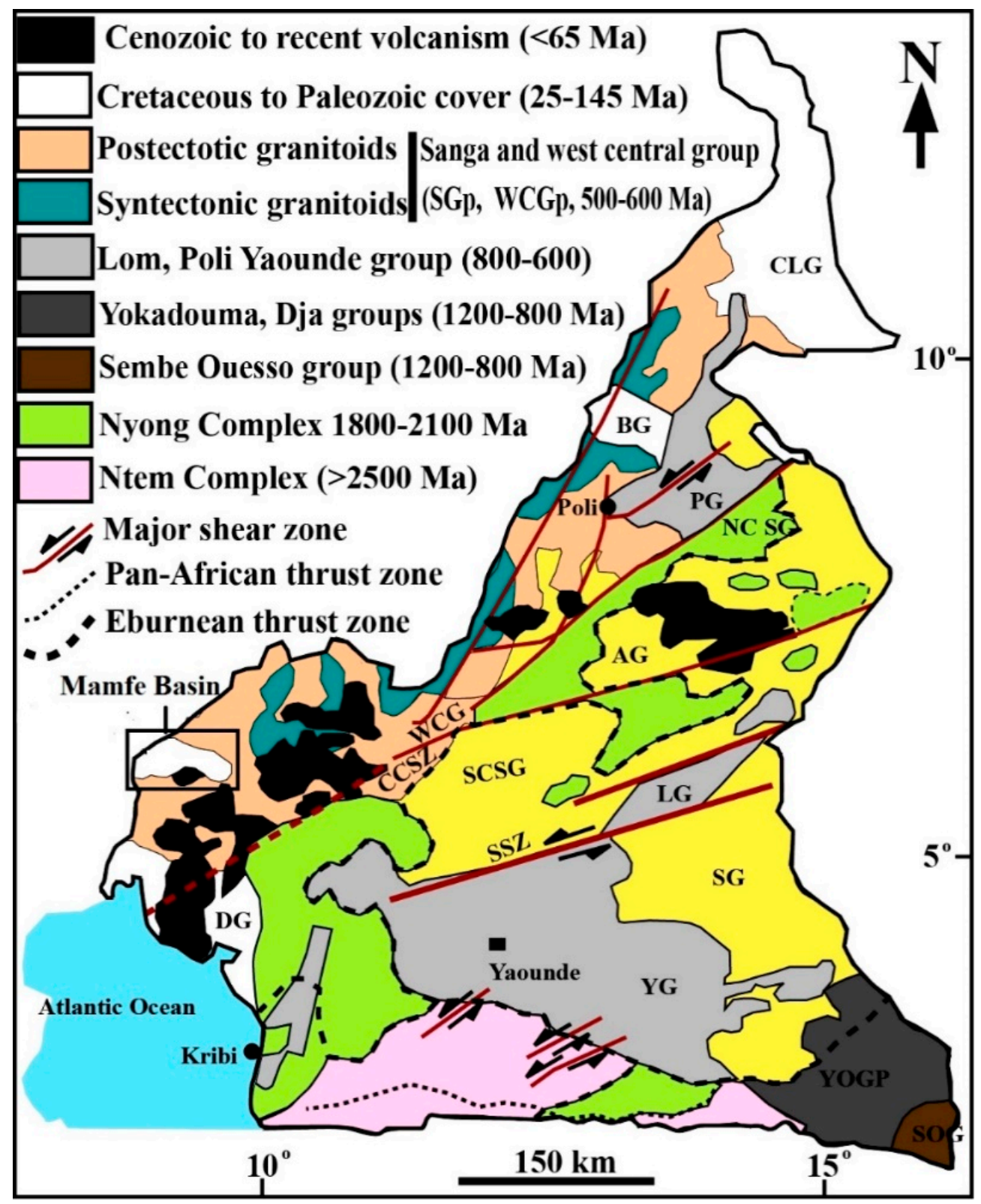

Figure 1. Sketched geological map of Cameroon (adapted from [101]). Oubanguide Complex: NCSG: Northern Cameroon SGp (PG: Poli Group, AG: Adamawa Group, WCG: West Cameroon Group); SCSG: Southern Cameroon SGp (YG: Yaoundé Group, LG: Lom Group, SG: Sanaga Group); SECSGp: Southeastern Cameroon SGp (DG: Dja, YoGroup: Yokadouma, S.O.Group: Sembe Ouesso Group); CCSZ: Centre Cameroon shear zone; SSZ: Sanaga shear zone; Sedimentary cover: (CLG: Chad Lake Group; BG: Benue Group; MG: Manfe Group; DG: Douala Group); B: Cameroon main lithostructural units). 


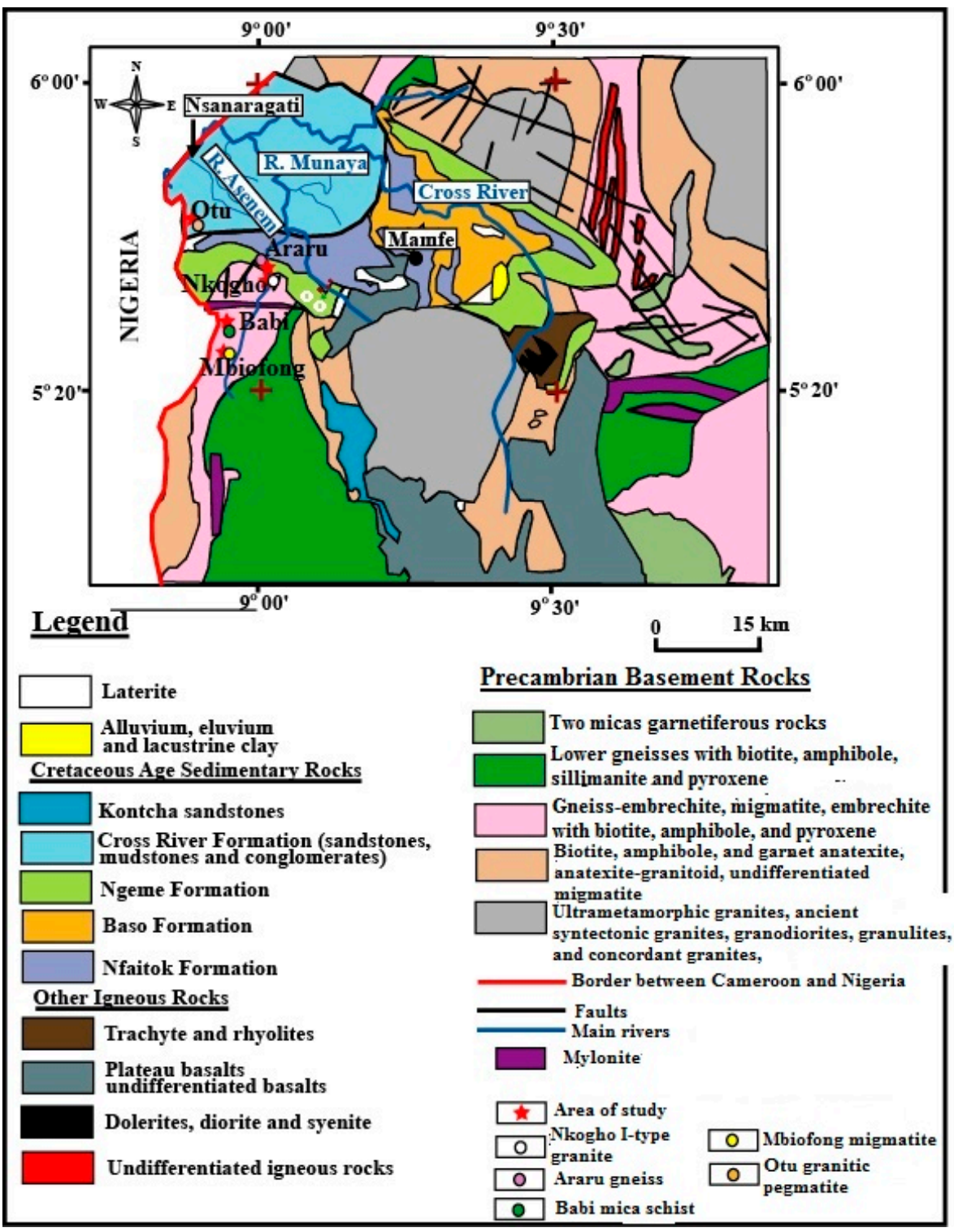

Figure 2. Sketched geologic map of the Mamfe Basin locating the study area and rocks from [38].

Basement rocks around the Mamfe Basin consist of gneisses, migmatites, granites, syenites, and mica schists (Figure 2) that recorded ductile and brittle cataclastic tectonomagmatic/metamorphic events $[5,6,36-38,106]$. The dominant strike direction for foliated rocks is $\mathrm{E}-\mathrm{W}$ with occasional swings to the $\mathrm{N}$ and $\mathrm{S}[36,37,106]$. Most gneisses belong to the Central African Mobile Zone or Cameroon Mobile Belt [37]. A recent study of the Otu granitic pegmatite (very coarse-grained to inequigranular) and Babi mica schist (slaty to weakly foliated and lepido-grano-porphyroblastic) show that they are, respectively, composed of: (1) microcline, orthoclase, mono to polycrystalline quartz, biotite, and clinopyroxene and (2) muscovite, biotite, and mono to polycrystalline quartz $[5,38]$. The obtained U-Pb zircon ages (ca. 490-653 Ma, close to those of most intrusive rocks within the Cameroon Mobile Belt) for the Otu granitic pegmatite dated to an Early Precambrian to Cambrian emplacement with progressive cooling of the source magma [5]. For [5], the Babi mica schist, with the variable U-Pb zircon ages (ca. 529-2019 Ma), was probably formed (during Calymmian period) from the metamorphic transformation of Paleoproterozoic clastic sediments sourced from magmatic rocks that were later affected by the PanAfrican tectono-metamorphic events. U-Pb zircon geochronology of arc-like and I-type granitoid outcropping in Nkogho in the south of this basin yielded an age range of 988 to $108 \mathrm{Ma}$, showing that this rock was formed during the Cryogenian to Ediacaran times and was later 
affected by post-Ediacaran-Cambrian to Albian magmatic events [6]. These Aptian-Albian ages probably date the opening of the Mamfe Basin [6].

The Mamfe Basin was essentially filled with continental clastic sediments (conglomerates, sandstones, arkoses, marlstones, siltstones, mudstones, and shales) with local limestones and evaporitic deposits [36,37,106-115]. Part of these rocks (mainly shales) enclose organic matter with some petroleum potential [114,116]. In the west, these Mamfe Basin rocks are locally overlain by Cenozoic to Paleoproterozoic sourced corundum-bearing placers $[21,22,38,117,118]$. Sedimentary rocks in the basin are locally cut by syenitic intrusions and doleritic dykes, or are overlain by trachytic and basaltic flows, and all are assumed to be Neogene in age $[36,38,119,120]$. Basaltic exposures that partly overlie sedimentary and basement rocks in the west and south of the basin include basanites, picro-basalts, alkali basalts, and tholeiitic basalts $[38,119]$. Undated phonolites, tephri-phonolites, trachytes, and basanites are found at Mount Nda Ali in the southeastern end of the basin [120]. In this area, those extrusive rocks overlie undated gabbros, diorites, monzonites, and syenites of alkaline affinity [120].

Data describing the zircon's source rocks are from earlier research [36-38]. The zircon crystals in this study are from two gneiss outcroppings in Araru and migmatite found in Mboifong in the southwestern part of the Mamfe Basin. Those in Araru are from black to whitish gneiss (AR1 zircons were sampled) and whitish-grey gneiss (AR2 zircons were sampled). Black to whitish gneiss locally outcrops as fragments in the west and northwestern part of Araru. Some of those fragments are cross-cut by quartzofeldspathic veinlets; large outcrops are rare. The black to whitish gneiss is made up of large amphibolepyroxene-bearing bands and large to thin felsic quartz, pink feldspar, and plagioclasebearing bands [36]. In the central part of Araru, whitish-grey gneiss outcrops occur. A $4 \mathrm{~m}$ (length) quartz-rich vein and medium-grained whitish-yellow rock separate the black to whitish gneiss and whitish-grey gneiss in the SW of Araru. Whitish-grey gneiss is composed of feldspar-rich large felsic bands (with microcline, plagioclase, and fractured and polycrystalline quartz) and thin biotite, orthopyroxene, and /or amphibole bearing grey bands [38]. The migmatite outcrop is found in the west of Mboifong. This rock is banded, faulted and folded. The faults and folds are filled with quartz-rich and quartzofeldspathic rocks [38]. Some outcrops are locally cross-cut by NNE-SSW, WNW-ESE, and NE-SW quartzofeldspathic veins and veinlets. Part of the veins and veinlets are faulted [38]. The faults show two directions (NNE-SSW and NE-SW) and cross-cut S-N bands. The felsic bands in this rock are mainly composed of quartz and feldspar, whereas the mafic bands enclose biotite, amphibole, and/or pyroxene [36,37].

\section{Materials and Methods}

Sample preparation and analytical procedures are the same as previously presented [6]. Heavy mineral concentrates with the studied zircon crystals were separated and preconcentrated at the Department of Earth Sciences (University of Yaoundé I, Yaoundé, Cameroon). They are from the crushed samples of the Araru black to whitish gneiss (AR1 zircons were sampled), Araru whitish-grey (AR2 zircons were sampled), and Mboifong migmatite. Twenty kilograms of fragments from each rock type were milled at the ALS mineral division laboratory in Mvan (Yaoundé, Cameroon). Before milling, precautions were taken to avoid any contamination. Samples were cleaned, chipped (to reduce grain size), crushed, and milled (at $1 \mathrm{~mm}$ grain size). Milled samples were regularly washed and panned for obtaining heavy mineral concentrates, which were later dried in an oven (for $24 \mathrm{~h}$, at $50^{\circ} \mathrm{C}$ ). Dried concentrates were sent to China for zircon separation, mounting, and BSE-CL imaging. Before mounting and BSE-CL imaging, zircon crystals were handpicked under a binocular microscope (ZEISS Stemi 2000-C), mounted with epoxy resin on a glass slide, and polished with abrasive to a standard thickness of $30 \mu \mathrm{m}$ at the China University of Geosciences, Wuhan, China.

Zircon's SEM-CL images were obtained by exposing mounted-polished crystals to cathodoluminescence imaging equipment at the Northwest University in Xi'an, China. The 
procedure used to acquire zircon's morphological features and internal texture is similar to that described earlier [31]. Images were taken using a CL detector attached to a scanning electron microscope (SEM-CL). The SEM-CL supported SEM backscattered electron (BSE) imaging. The obtained SEM-CL imaging was used to classify zircon based on features presented in $[19,31]$.

The procedure used for U-Pb zircon dating followed the accepted procedure at CUG Wuhan [121]. The polished slabs were analyzed using a modern $193 \mathrm{~nm}$ ArF excimer laser ablation (LA) and quadrupole-inductively coupled plasma-mass spectrometry (QICP-MS) instrumentation. Data on $\mathrm{Th}, \mathrm{U}$, and $\mathrm{Pb}$ abundance and $\mathrm{U}-\mathrm{Pb}$ age were obtained from craters $(33 \mu \mathrm{m}$ of diameter and $<20 \mu \mathrm{m}$ of depth) targeted in the core and rim of each zircon crystal and any oscillatory zones (Figures 3-5). They were obtained by combining enhanced ICP-MS sensitivity, fast and efficient sample cells, and sophisticated software controls, modern 193 nm ArF excimer LA-ICPMS systems. As in [121], the ablation conditions were typically matched with an ICP-MS time-resolved analyse (TRA) method that takes advantage of the very fast peak-hopping capabilities of the quadrupole mass filter. For U-Pb geochronology, the dwell times (measured in $\mathrm{ms}$ ) are typically ${ }^{207} \mathrm{~Pb}>{ }^{206} \mathrm{~Pb}>{ }^{208} \mathrm{~Pb}>{ }^{232} \mathrm{Th}>{ }^{238} \mathrm{U}$. This order reflects (1) the diminishing abundance of $\mathrm{Pb}$ isotopes; (2) the need to ensure that the ${ }^{207} \mathrm{~Pb} /{ }^{206} \mathrm{~Pb}$ ratio has the highest precision and; (3) the higher absolute concentration and ion transmission through the ICP-MS of U and Th. Dwell times are typically $10-20 \mathrm{~ms}$ for ${ }^{208} \mathrm{~Pb},{ }^{232} \mathrm{Th}$, and ${ }^{238} \mathrm{U}$ and somewhat longer dwell times of ${ }^{206} \mathrm{~Pb},{ }^{207} \mathrm{~Pb}$, and ${ }^{204} \mathrm{~Pb} 30-80 \mathrm{~ms}$ for (if the latter is even analyzed). The goal of this setup was to ensure that a single sweep of the quadrupole was almost instantaneous, that a large number of measurements per second were obtained, and that a sufficient number of ions were counted for each mass (see, for example, [122]). Adding up individual dwell times plus quadrupole settling time $(<1 \mathrm{~ms})$ typically yielded total integration times $=0.25 \mathrm{~s}$ so that a 35-s ablation would yield $\sim 140$ independent measurements of ${ }^{207} \mathrm{~Pb} /{ }^{206} \mathrm{~Pb},{ }^{206} \mathrm{~Pb} /{ }^{238} \mathrm{U}$, and ${ }^{208} \mathrm{~Pb} /{ }^{232} \mathrm{Th}\left({ }^{207} \mathrm{~Pb} /{ }^{235} \mathrm{U}\right.$ is calculated offline using the natural abundance of $\left.{ }^{235} \mathrm{U} /{ }^{238} \mathrm{U}=1 / 137.88\right)$. Using this approach allows ArF excimer LA-ICPMS to achieve short-term precision, expressed as the relative standard deviation (\%RSD) for the raw ${ }^{207} \mathrm{~Pb} /{ }^{206} \mathrm{~Pb},{ }^{206} \mathrm{~Pb} /{ }^{238} \mathrm{U}$, and ${ }^{207} \mathrm{~Pb} /{ }^{235} \mathrm{U}$ in the range of 0.5 to $3.5 \%$. The data were corrected for instrument drift and processed with Iolite ${ }^{\mathrm{TM}}$ and VizualAge ${ }^{\mathrm{TM}}$, which helps refine the standard time integrations to achieve the most coherent population. The precision for ${ }^{207} \mathrm{~Pb} /{ }^{206} \mathrm{~Pb}$ was optimized by using the longest dwell times for ${ }^{207} \mathrm{~Pb}$ (75 ms) and ${ }^{206} \mathrm{~Pb}(30 \mathrm{~ms})$, thereby ensuring that error ellipses on a conventional Concordia diagram have positive error correlations and were plotted using Isoplot [123].

\section{Results}

Grain size, morphology, internal texture, $\mathrm{U}-\mathrm{Th}-\mathrm{Pb}$ concentrations, and $\mathrm{U}-\mathrm{Pb}$ ages for zircon crystals from black to whitish gneiss (AR1), whitish-grey gneiss (AR2), and Mboifong migmatite (MBF) are presented separately. U-Pb zircon ages for Otu granitic pegmatite, Babi mica schist, and Nkogho anatectic granite, previously published $[5,6]$, are updated.

\subsection{Zircon Grain Size, Morphology, and Internal Texture for Araru Gneisses and Mbiofong Migmatite}

\subsubsection{Zircon Crystals from Black to Whitish Gneiss}

The grain size for zircon crystals from black to whitish gneiss (Figure 3) ranges from 50 to $300 \mu \mathrm{m}$, with most of their sizes $>100 \mu \mathrm{m}$. The crystals are dominantly euhedral prismatic and prismatic and/or pyramidal to dipyramidal with truncated terminal faces. Some crystals are equant; very few are subrounded, pitted, flat, twinned, or show a subrounded or dipyramidal core. Minor crystals host cracks or are fragments. Texturally, they mainly exhibit growth zoning. Few crystals are unzoned, or show complex zoning (such as faint-broad, convolute, sector, or bulbous replacement zoning), or show core and rim differences, based on [31] classification. 


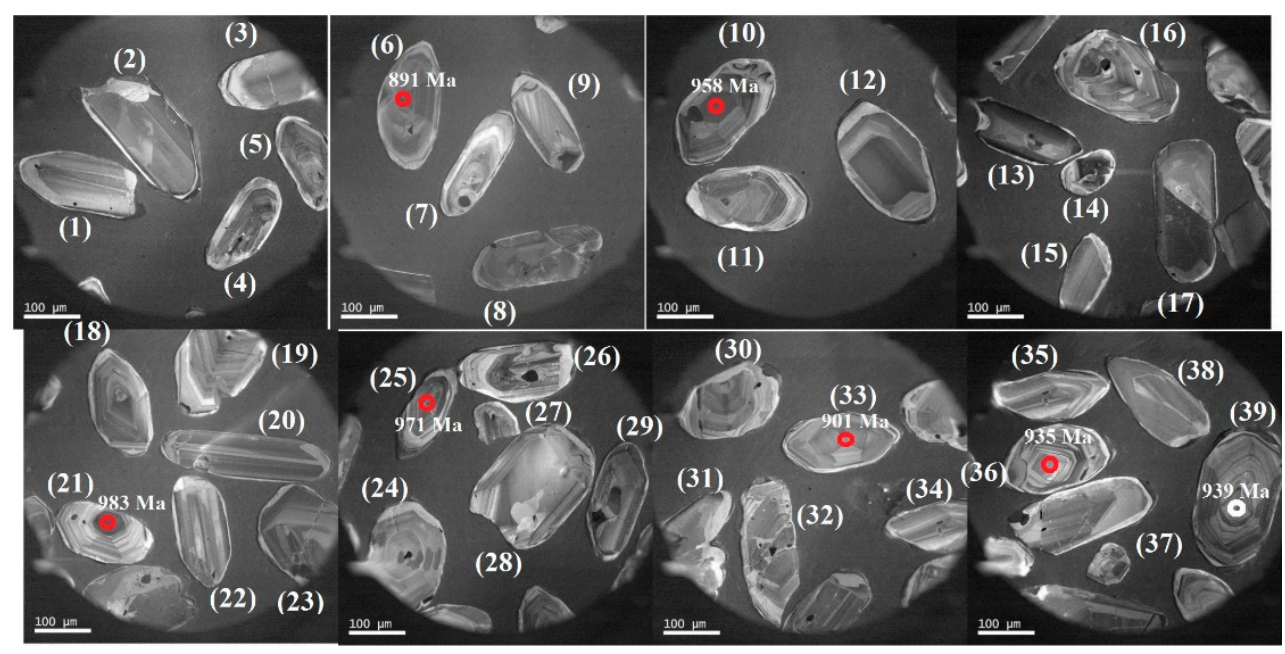

Figure 3. BSE-CL images showing internal texture of zircon crystals with analyzed spots (from Araru black to whitish gneiss).

\subsubsection{Zircon Crystals from Whitish-Grey Gneiss}

Zircon crystals from whitish-grey gneiss (AR2) are dominantly greater than $100 \mu \mathrm{m}$ (Figure 4). They form full or crystal fragments. They are mainly euhedral with very few subhedral, anhedral, or subrounded grains. Crystal fragments show almost conchoidal fracture. These zircon fragments may be grains fractured during post emplacement tectonism. Euhedral crystals are prismatic and pyramidal to dipyramidal, with few subrounded cores. Anhedral grains totally lack prismatic faces and are subrounded. Euhedral and subhedral crystals are zoned, pitted, or show a core and rim difference with newly grown domains. Few show patchy zoning, complex zoning, or are unzoned but lack a pronounced growth zoning and faint and broad zoning. Few crystals show a subrounded dark core surrounded with developed prismatic and dipyramidal bright and dark zones; others show a magmatically resorbed feature, local recrystallization, and convolute zoning similar to features previously presented [31].

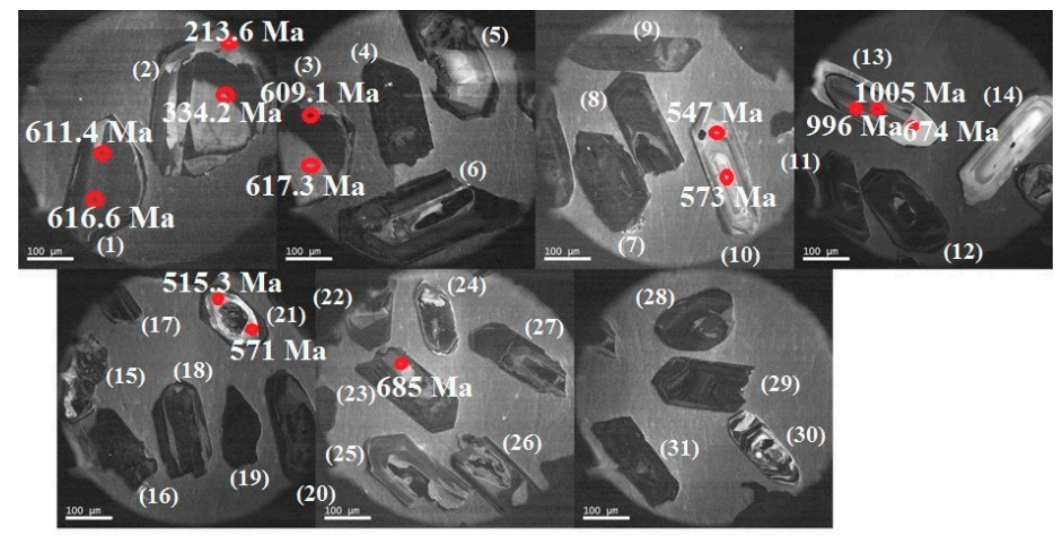

Figure 4. BSE-CL images showing internal texture of zircon crystals with analyzed spots (from Araru whitish-grey gneiss).

\subsubsection{Zircon Crystals from Mboifong Migmatite}

Zircon crystals from Mboifong migmatite are dominantly greater than $100 \mu \mathrm{m}$ (Figure 5). They are mainly euhedral, forming long and short prisms, with part of the crystals being pyramidal and/or dipyramidal. Few zircons show twinning or are anhedral or subrounded. Most crystals show core and rim differences with a new overgrowth zone. Part of the zircon's core is rounded, subrounded, prismatic or zoned (features similar to those of xenocrystic cores presented in [31]). The studied zircons show complex growth zoning, 
patchy zoning, local recrystallization, and recrystallization at crystal terminations (close to feature for zircons from high-grade metamorphic rocks presented in [31]), convolute zoning or are unzoned.

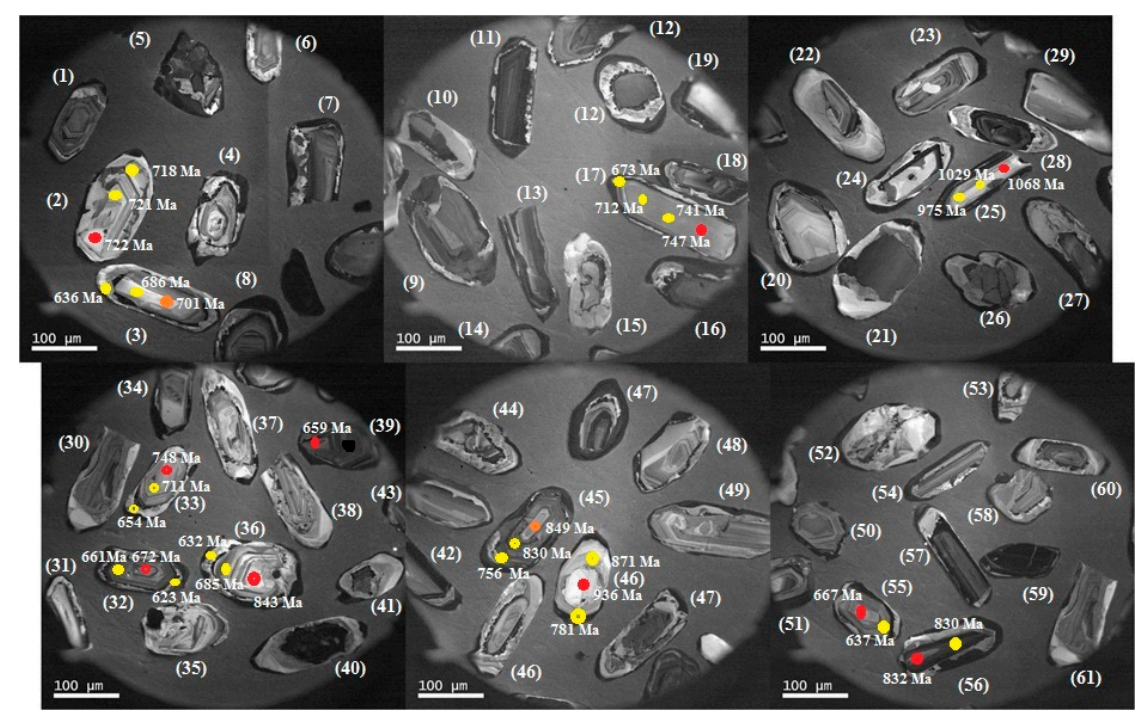

Figure 5. BSE-CL images showing internal texture of zircon crystals with analyzed spots (from Mboifong migmatite).

\subsection{Zircon U-Th-Pb and U-Pb Age for Araru Gneisses and Mbiofong Migmatite}

The $\mathrm{U}, \mathrm{Th}$, and $\mathrm{Pb}$ contents and $\mathrm{U}-\mathrm{Pb}$ ages in the core of the zircon crystals from black to whitish gneiss (Table 2), and at $C$ and $R$ spots in zircons from whitish-grey banded gneiss, and those from Mboifong migmatite are variable (Tables 3 and 4).

\subsubsection{Zircon Crystals from Black to Whitish Gneiss}

The $\mathrm{U}$ contents in the core of zircon crystals from black to whitish gneiss range from 42 to $131 \mathrm{ppm}$ (Table 2). The Th and Pb contents vary from 41 to $189 \mathrm{ppm}$ and 19 to 82 ppm, respectively (Table 2). The calculated Th/U ratios, varying from 0.93 to 1.50 , are within the range limit in magmatic zircons presented in $[5,35,124]$. The ${ }^{206} \mathrm{~Pb} /{ }^{238} \mathrm{U}$ and ${ }^{207} \mathrm{~Pb} /{ }^{235} \mathrm{U}$ ages (Table 2 and Figure 6a) range from $875 \pm 15$ to $975 \pm 15 \mathrm{Ma}$, and $891 \pm 15$ to $983 \pm 10 \mathrm{Ma}$, respectively. These ages date Early Neoproterozoic (Tonian) crystallization features.

\subsubsection{Zircon Crystals from Whitish-Grey Gneiss}

The $\mathrm{U}$ contents at spot $\mathrm{C}$ on zircon crystals from whitish-grey gneiss range from 79 to $2610 \mathrm{ppm}$. The Th and $\mathrm{Pb}$ contents vary from 3.8 to $138 \mathrm{ppm}$ and 5.9 to $64.6 \mathrm{ppm}$, respectively. The calculated $\mathrm{Th} / \mathrm{U}$ ratios vary from 0.005 to 0.890 , with most values being within the range of metamorphic zircons presented in [11]. The ${ }^{206} \mathrm{~Pb} /{ }^{238} \mathrm{U}$ and ${ }^{207} \mathrm{~Pb} /{ }^{235} \mathrm{U}$ ages (Table 3 and Figure $6 \mathrm{~b}$ ) range from $333.5 \pm 9.6$ to $999.8 \pm 14.0 \mathrm{Ma}$, and, $334.2 \pm 8.8 \mathrm{Ma}$ to $996 \pm 11 \mathrm{Ma}$, respectively. These ages date Early Neoproterozoic (Tonian), Mid Neoproterozoic (Cryogenian), Late Neoproterozoic (Ediacaran), and Early Carboniferous (Visian) crystallization episodes. The $U$ contents at spots $\mathrm{R}$ on zircon crystals from whitish-grey gneiss range from 8.7 to $1690 \mathrm{ppm}$. The Th and $\mathrm{Pb}$ contents vary from 0.04 to $290 \mathrm{ppm}$ and 0.06 to $134.2 \mathrm{ppm}$. The calculated Th/U ratios vary from 0.007 to 2.15 , with most values being below 0.03 . The obtained ${ }^{206} \mathrm{~Pb} /{ }^{238} \mathrm{U}$ and ${ }^{207} \mathrm{~Pb} /{ }^{235} \mathrm{U}$ ages (Table 3 and Figure $6 \mathrm{~b}$ ) range from $212 \pm 11 \mathrm{Ma}$ to $1006 \pm 14 \mathrm{Ma}$ and $213 \pm 14 \mathrm{Ma}$ to $1005 \pm 9.1 \mathrm{Ma}$. These ages date from the Late Mesoproterozoic to the Early Neoproterozoic, Mid Neoproterozoic (Cryogenian), Late Neoproterozoic (Ediacaran), and Late Triassic events. 
Table 2. Trace element and U-Pb isotopic results (zircon from Araru black to whitish gneiss) with C in the spotted area.

\begin{tabular}{|c|c|c|c|c|c|c|c|c|c|c|c|c|c|c|c|c|c|}
\hline \multirow{3}{*}{$\begin{array}{c}\text { Crystal and Spot Number } \\
\text { AR1-7-C }\end{array}$} & \multirow{3}{*}{$\begin{array}{l}\text { Analysis No. } \\
\text { Output_1_19 }\end{array}$} & \multicolumn{4}{|c|}{ Ages (Ma) } & \multicolumn{8}{|c|}{ Atomic Ratios (\%) } & \multicolumn{4}{|c|}{ Concentrations (ppm) } \\
\hline & & \multicolumn{2}{|c|}{${ }^{206} \mathrm{~Pb}^{238} \mathrm{U}$ Prop_2SE } & \multicolumn{2}{|c|}{${ }^{207} \mathrm{~Pb} /{ }^{235} \mathrm{U}$ Prop_2SE } & \multicolumn{2}{|c|}{${ }^{206} \mathrm{~Pb} /{ }^{238} \mathrm{U}$ Prop_2SE } & \multicolumn{2}{|c|}{${ }^{207} \mathrm{~Pb} /{ }^{235} \mathrm{U}$ Prop_2SE } & \multicolumn{2}{|c|}{${ }^{207} \mathrm{~Pb} /{ }^{206} \mathrm{~Pb}$ Prop_2SE } & \multicolumn{2}{|c|}{${ }^{208} \mathrm{~Pb} / 232 \mathrm{Th}$ Prop_2SE } & \multirow{2}{*}{\begin{tabular}{|c|}
$\mathbf{U}$ \\
77.2
\end{tabular}} & \multirow{2}{*}{$\begin{array}{c}\text { Th } \\
72.3\end{array}$} & \multirow{2}{*}{\begin{tabular}{|c|}
$\mathbf{P b}$ \\
35.4
\end{tabular}} & \multirow{3}{*}{$\begin{array}{l}\text { Th/U } \\
0.9365\end{array}$} \\
\hline & & 959 & 14 & 958 & 12 & 0.1611 & 0.0024 & 1.62 & 0.052 & 0.0725 & 0.002 & 0.051 & 0.0018 & & & & \\
\hline AR1-6-C & Output_1_17 & 951.3 & 14 & 935 & 16 & 0.1604 & 0.0025 & 1.739 & 0.056 & 0.0783 & 0.0026 & 0.055 & 0.0023 & 42.62 & 41.7 & 22.6 & \\
\hline AR1-5-C & Output_1_16 & 941.7 & 14 & 939 & 11 & 0.1577 & 0.0023 & 1.542 & 0.032 & 0.0705 & 0.0014 & 0.048 & 0.0015 & 83.2 & 114 & 50.8 & 1.3701 \\
\hline AR1-4-C & Output_1_15 & 968.7 & 13 & 983 & 10 & 0.1627 & 0.0023 & 1.654 & 0.026 & 0.0741 & 0.0012 & 0.049 & 0.0014 & 101.7 & 151 & 73.2 & 1.4847 \\
\hline AR1-3-C & Output_1_14 & 875.6 & 15 & 891 & 15 & 0.147 & 0.0024 & 1.588 & 0.026 & 0.078 & 0.0013 & 0.046 & 0.0014 & 130.6 & 189 & 81.1 & 1.4471 \\
\hline AR1-2-C & Output_1_13 & 975.7 & 15 & 971 & 13 & 0.1638 & 0.0024 & 1.638 & 0.039 & 0.0721 & 0.0017 & 0.048 & 0.0016 & 59.6 & 60.9 & 27.3 & 1.0218 \\
\hline AR1-1-C & Output_1_12 & 901.4 & 14 & 901 & 13 & 0.1505 & 0.0025 & 1.489 & 0.045 & 0.0711 & 0.002 & 0.047 & 0.0018 & 43.71 & 42.79 & 19.27 & 0.9789 \\
\hline
\end{tabular}

Prop_2SE. Propagated 2 standard errors.

Table 3. Trace element and U-Pb isotopic results (zircon from Araru whitish-grey gneiss) with $\mathrm{C}$ and $\mathrm{R}$ in the spotted areas.

\begin{tabular}{|c|c|c|c|c|c|c|c|c|c|c|c|c|c|c|c|c|c|}
\hline \multirow{3}{*}{$\begin{array}{c}\text { Crystal and Spot Number } \\
\text { AR2-7-R }\end{array}$} & \multirow{3}{*}{$\begin{array}{l}\text { Analysis No. } \\
\text { Output_1_34 }\end{array}$} & \multicolumn{4}{|c|}{ Ages (Ma) } & \multicolumn{8}{|c|}{ Atomic Ratios (\%) } & \multicolumn{4}{|c|}{ Concentrations (ppm) } \\
\hline & & \multicolumn{2}{|c|}{${ }^{206} \mathrm{~Pb} /{ }^{238} \mathrm{U}$ Prop_2SE } & \multicolumn{2}{|c|}{${ }^{207} \mathrm{~Pb} / 235 \mathrm{U}$ Prop_2SE } & \multicolumn{2}{|c|}{${ }^{206} \mathrm{~Pb} /{ }^{238} \mathrm{U}$ Prop_2SE } & \multicolumn{2}{|c|}{${ }^{207} \mathrm{~Pb} /{ }^{235} \mathrm{U}$ Prop_2SE } & \multicolumn{2}{|c|}{${ }^{207} \mathrm{~Pb} /{ }^{206} \mathrm{~Pb}$ Prop_2SE } & \multicolumn{2}{|c|}{${ }^{208} \mathrm{~Pb} /{ }^{232} \mathrm{Th}$ Prop_2SE } & \multirow{2}{*}{$\begin{array}{c}\mathbf{U} \\
134.2\end{array}$} & \multirow{2}{*}{\begin{tabular}{|c|c|} 
Th \\
289.8
\end{tabular}} & \multirow{2}{*}{\begin{tabular}{|c|}
$\mathbf{P b}$ \\
134.2
\end{tabular}} & \multirow{2}{*}{$\begin{array}{l}\mathrm{Th} / \mathrm{U} \\
2.1594\end{array}$} \\
\hline & & 740 & 20 & 685 & 25 & 0.131 & 0.0032 & 2.033 & 0.051 & 0.114 & 0.0027 & 0.053 & 0.002 & & & & \\
\hline AR2-6-R & Output_1_32 & 498.2 & 9.6 & 515.3 & 7.8 & 0.082 & 0.0017 & 0.806 & 0.028 & 0.072 & 0.0016 & 0.108 & 0.024 & 3210 & 96.9 & 86.2 & 0.0302 \\
\hline AR2-6-C & Output_1_33 & 544 & 8.7 & 571 & 6.3 & 0.088 & 0.0014 & 0.776 & 0.013 & 0.064 & 0.0007 & 0.14 & 0.024 & 2610 & 26.4 & 30.1 & 0.0101 \\
\hline AR2-5-R1 & Output_1_31 & 1006 & 14 & 1005 & 9.1 & 0.169 & 0.0024 & 1.681 & 0.028 & 0.072 & 0.0011 & 0.053 & 0.002 & 119.3 & 102.7 & 49 & 0.8608 \\
\hline AR2-5-R2 & Output_1_30 & 670 & 20 & 674 & 19 & 0.11 & 0.0035 & 0.967 & 0.12 & 0.065 & 0.0066 & 0.04 & 0.49 & 8.78 & 0.0044 & 0.063 & 0.005 \\
\hline AR2-4-R1 & Output_1_26 & 553.8 & 9.8 & 547 & 10 & 0.09 & 0.0016 & 0.752 & 0.075 & 0.061 & 0.0045 & 0.028 & 0.001 & 79.5 & 120.3 & 33.9 & 1.5132 \\
\hline AR2-4-C & Output_1_28 & 579 & 9.5 & 573 & 13 & 0.097 & 0.0024 & 1.005 & 0.19 & 0.075 & 0.011 & 0.034 & 0.003 & 91.6 & 80.7 & 23.9 & 0.881 \\
\hline AR2-3-R & Output_1_24 & 212.8 & 11 & 213.6 & 14 & 0.035 & 0.0039 & 0.463 & 0.29 & 0.095 & 0.012 & 0.46 & 0.4 & 1690 & 11.79 & 56 & 0.007 \\
\hline AR2-3-C & Output_1_25 & 333.5 & 9.6 & 334.2 & 8.8 & 0.056 & 0.0016 & 0.688 & 0.018 & 0.09 & 0.002 & 0.362 & 0.021 & 315.5 & 3.84 & 13.37 & 0.0122 \\
\hline AR2-2-R & Output_1_23 & 605.9 & 8.3 & 611.4 & 6.1 & 0.099 & 0.0014 & 0.833 & 0.013 & 0.062 & 0.001 & 0.05 & 0.005 & 296 & 6.1 & 2.92 & 0.0206 \\
\hline AR2-1C & Output_1_20 & 611 & 7.6 & 617.3 & 3.4 & 0.099 & 0.0013 & 0.839 & 0.006 & 0.061 & 0.0005 & 0.033 & 0.002 & 843 & 22.9 & 7.08 & 0.0272 \\
\hline AR2-1R & Output_1_21 & 606.8 & 7.6 & 609.1 & 4.6 & 0.099 & 0.0013 & 0.824 & 0.008 & 0.06 & 0.0005 & 0.031 & 0.002 & 890 & 25.42 & 7.44 & 0.0286 \\
\hline
\end{tabular}

Prop_2SE. Propagated 2 standard errors. 
Table 4. Trace element and U-Pb isotopic results (zircon from Mboifong migmatite) with $\mathrm{C}$ and $\mathrm{R}$ in the spotted areas.

\begin{tabular}{|c|c|c|c|c|c|c|c|c|c|c|c|c|c|c|c|c|c|}
\hline \multirow{2}{*}{ Crystal and Spot Number } & \multirow{2}{*}{ Analysis No. } & \multicolumn{3}{|c|}{ Ages (Ma) } & \multicolumn{9}{|c|}{ Atomic Ratios (\%) } & \multicolumn{4}{|c|}{ Concentrations (ppm) } \\
\hline & & ${ }^{206} \mathrm{~Pb} /{ }^{238} \mathrm{U}$ & Prop_2SE & ${ }^{207} \mathrm{~Pb} /{ }^{235} \mathrm{U}$ & Prop_2SE & ${ }^{206} \mathrm{~Pb} /{ }^{238} \mathrm{U}$ & Prop_2SE & ${ }^{207} \mathrm{~Pb} /{ }^{235} \mathrm{U}$ & Prop_2SE & ${ }^{207} \mathrm{~Pb} /{ }^{206} \mathrm{~Pb}$ & Prop_2SE & $208 \mathrm{~Pb} / 232 \mathrm{Th}$ & Prop_2SE & $\mathrm{U}$ & Th & $\mathrm{Pb}$ & $\mathrm{Th} / \mathrm{U}$ \\
\hline MBFR-1 & Output_1_48 & 673.1 & 5.7 & 670.2 & 11 & 0.110 & 0.0010 & 0.935 & 0.022 & 0.062 & 0.0013 & 0.034 & 0.0008 & 246.2 & 132.4 & 40.8 & 0.538 \\
\hline MBF1-C & Output_1_32 & 747.6 & 9.3 & 742.3 & 13 & 0.123 & 0.0016 & 1.079 & 0.026 & 0.064 & 0.0013 & 0.037 & 0.0007 & 227.9 & 225.1 & 80.5 & 0.988 \\
\hline MBF1-R1 & Output_1_33 & 741.8 & 7.6 & 750 & 13 & 0.122 & 0.0013 & 1.091 & 0.026 & 0.065 & 0.0014 & 0.037 & 0.0008 & 168.4 & 143.6 & 52.5 & 0.853 \\
\hline MBF1-R2 & Output_1_31 & 712 & 8.8 & 735 & 16 & 0.117 & 0.0015 & 1.061 & 0.032 & 0.067 & 0.0019 & 0.035 & 0.001 & 138.7 & 103 & 36.9 & 0.743 \\
\hline MBF2-C & Output_1_35 & 975.9 & 8.5 & 982 & 17 & 0.164 & 0.0015 & 1.631 & 0.043 & 0.073 & 0.0017 & 0.048 & 0.0015 & 117.3 & 82 & 38.6 & 0.699 \\
\hline MBF2-C-2 & Output_1_36 & 1029.7 & 9.3 & 1022.5 & 15 & 0.173 & 0.0017 & 1.741 & 0.041 & 0.073 & 0.0015 & 0.049 & 0.0011 & 137.3 & 88.9 & 41.6 & 0.647 \\
\hline MBF2-R1 & Output_1_34 & 1068 & 15 & 1040 & 18 & 0.180 & 0.0028 & 1.787 & 0.049 & 0.072 & 0.0017 & 0.056 & 0.0015 & 130.4 & 69.5 & 38.8 & 0.533 \\
\hline MBF3-C & Output_1_37 & 721.4 & 5.7 & 732.4 & 12 & 0.118 & 0.0010 & 1.062 & 0.026 & 0.065 & 0.0014 & 0.037 & 0.0008 & 333 & 132.8 & 46.7 & 0.399 \\
\hline MBF3-R1 & Output_1_39 & 718.9 & 7.9 & 724.6 & 12 & 0.118 & 0.0014 & 1.039 & 0.024 & 0.0641 & 0.0013 & 0.036 & 0.0008 & 385 & 172 & 61.3 & 0.447 \\
\hline MBF3-R2 & Output_1_38 & 722.7 & 7.3 & 737.6 & 13 & 0.119 & 0.0013 & 1.074 & 0.029 & 0.066 & 0.0015 & 0.037 & 0.0012 & 394 & 173 & 59.1 & 0.439 \\
\hline MBF4-R2 & Output_1_40 & 701.1 & 5.6 & 683.3 & 12 & 0.115 & 0.0010 & 0.96 & 0.023 & 0.061 & 0.0013 & 0.032 & 0.0006 & 365 & 229 & 68 & 0.627 \\
\hline MBF4R1 & Output_1_43 & 636 & 8.1 & 629 & 14 & 0.104 & 0.0014 & 0.86 & 0.026 & 0.060 & 0.0016 & 0.030 & 0.0007 & 119.9 & 139.1 & 38.8 & 1.160 \\
\hline MBF5-C & Output_1_44 & 748 & 13 & 716 & 15 & 0.123 & 0.0024 & 1.028 & 0.029 & 0.061 & 0.0011 & 0.035 & 0.0008 & 940 & 332 & 100.6 & 0.353 \\
\hline MBF5R1 & Output_1_45 & 711 & 7.2 & 692.4 & 12 & 0.117 & 0.0012 & 0.976 & 0.023 & 0.062 & 0.0012 & 0.034 & 0.0008 & 235 & 143.3 & 45.9 & 0.610 \\
\hline MBF5R2 & Output_1_46 & 654 & 15 & 642 & 14 & 0.107 & 0.0026 & 0.886 & 0.027 & 0.061 & 0.0012 & 0.047 & 0.0043 & 780 & 26.1 & 11.1 & 0.033 \\
\hline MBF6-C & Output_1_47 & 659.5 & 4.3 & 656,5 & 11 & 0.108 & 0.0007 & 0.909 & 0.021 & 0.061 & 0.0012 & 0.033 & 0.0008 & 255 & 114.7 & 34.57 & 0.450 \\
\hline MBF7-C & Output_1_49 & 632.1 & 10 & 625 & 12 & 0.103 & 0.0017 & 0.851 & 0.023 & 0.060 & 0.0013 & 0.049 & 0.0062 & 273.6 & 4.47 & 2.17 & 0.016 \\
\hline MBF7-R1 & Output_1_51 & 685 & 12 & 677 & 18 & 0.112 & 0.002 & 0.955 & 0.035 & 0.061 & 0.0017 & 0.25 & 0.12 & 102.8 & 0.275 & 0.29 & 0.003 \\
\hline MBF7-R2 & Output_1_50 & 843.8 & 10 & 842 & 21 & 0.140 & 0.0018 & 1.302 & 0.046 & 0.068 & 0.0021 & 0.040 & 0.0012 & 71.3 & 64.6 & 24.19 & 0.906 \\
\hline MBF8-C & Output_1_52 & 672.5 & 5 & 661,3 & 10 & 0.110 & 0.0008 & 0.917 & 0.02 & 0.061 & 0.0012 & 0.032 & 0.0005 & 463 & 398 & 118.6 & 0.860 \\
\hline MBF8-R1 & Output_1_53 & 661.4 & 4.6 & 660 & 11 & 0.108 & 0.0008 & 0.916 & 0.02 & 0.062 & 0.0012 & 0.032 & 0.0006 & 406 & 422 & 124.8 & 1.039 \\
\hline MBF8-R2 & Output_1_54 & 623.5 & 5 & 624.6 & 9.7 & 0.102 & 0.0009 & 0.850 & 0.018 & 0.061 & 0.0011 & 0.031 & 0.0005 & 971 & 914 & 265.9 & 0.941 \\
\hline MBF9-R & Output_1_57 & 781 & 23 & 787 & 20 & 0.129 & 0.004 & 1.17 & 0.043 & 0.066 & 0.0015 & 0.065 & 0.0085 & 225 & 27.2 & 13.37 & 0.121 \\
\hline MBF10-C & Output_1_58 & 756.1 & 9.9 & 763.9 & 13 & 0.124 & 0.0017 & 1.124 & 0.027 & 0.066 & 0.0012 & 0.039 & 0.0007 & 652 & 274 & 95.6 & 0.420 \\
\hline MBF10-R1 & Output_1_59 & 830.9 & 7.2 & 871 & 15 & 0.138 & 0.0013 & 1.359 & 0.035 & 0.072 & 0.0017 & 0.048 & 0.0012 & 255.8 & 124.6 & 54.8 & 0.487 \\
\hline MBF10-R2 & Output_1_60 & 849.3 & 8.4 & 828.1 & 13 & 0.141 & 0.0015 & 1.263 & 0.03 & 0.066 & 0.0013 & 0.044 & 0.0009 & 322.8 & 252 & 103.1 & 0.781 \\
\hline MBF11-C & Output_1_61 & 832.1 & 9.1 & 829.4 & 13 & 0.138 & 0.0017 & 1.263 & 0.03 & 0.067 & 0.0014 & 0.043 & 0.0009 & 241 & 151.2 & 60.3 & 0.627 \\
\hline MBF11-R2 & Output_1_62 & 830.5 & 8.6 & 823.7 & 14 & 0.137 & 0.0015 & 1.252 & 0.031 & 0.066 & 0.0014 & 0.043 & 0.001 & 182.2 & 101 & 39.6 & 0.554 \\
\hline MBF12-C & Output_1_63 & 667 & 6.7 & 663 & 14 & 0.109 & 0.0012 & 0.924 & 0.027 & 0.062 & 0.0016 & 0.034 & 0.0011 & 133.9 & 78.8 & 24.16 & 0.588 \\
\hline MBF12-R & Output_1_64 & 637.4 & 5.5 & 639.4 & 11 & 0.104 & 0.0009 & 0.878 & 0.021 & 0.061 & 0.0013 & 0.032 & 0.0007 & 240 & 147.3 & 44.8 & 0.614 \\
\hline
\end{tabular}




\subsubsection{Zircon Crystals from Mboifong Migmatite}

The $\mathrm{U}$ contents at spot $\mathrm{C}$ on zircon crystals from Mboifong migmatite range from 106 to $940 \mathrm{ppm}$ (Table 4). The Th and Pb contents vary from 4 to $332 \mathrm{ppm}$ and 2 to $101 \mathrm{ppm}$, respectively. The calculated $\mathrm{Th} / \mathrm{U}$ ratios vary from 0.016 to 0.99 , with the lowest value found in MBF7-C and most values being greater than 0.3 . The ${ }^{206} \mathrm{~Pb} /{ }^{238} \mathrm{U}$ and ${ }^{207} \mathrm{~Pb} /{ }^{235} \mathrm{U}$ ages (Table 4 and Figure 6c) range $632 \pm 10 \mathrm{Ma}$ to $1030 \pm 9.3 \mathrm{Ma}$, and $625 \pm 25$ to $1022 \pm 15 \mathrm{Ma}$, respectively. These ages predominantly date Mid Neoproterozoic (Cryogenian) episodes with few spots showing Late Neoproterozoic (Ediacaran), Early Neoproterozoic (Tonian), or Late Mesoproterozoic period. The U contents at spot R on zircon crystals from the same rock range from 84 to $971 \mathrm{ppm}$. The Th and $\mathrm{Pb}$ contents vary from 0.2 to $914 \mathrm{ppm}$ and 0.2 to $266 \mathrm{ppm}$, respectively. The calculated Th/U ratios vary from 0.003 to 1.16 , with most values being greater than 0.4 . The ${ }^{206} \mathrm{~Pb} /{ }^{238} \mathrm{U}$ and ${ }^{207} \mathrm{~Pb} /{ }^{235} \mathrm{U}$ ages range from $623 \pm 5 \mathrm{Ma}$ to $1068 \pm 15 \mathrm{Ma}$, and $624 \pm 9.7 \mathrm{Ma}$ to $1040 \pm 18 \mathrm{Ma}$. These ages predominantly date the Mid Neoproterozoic (Cryogenian) episode, with few spots showing Late Neoproterozoic (Ediacaran), Early Neoproterozoic (Tonian), and Late Mesoproterozoic periods.
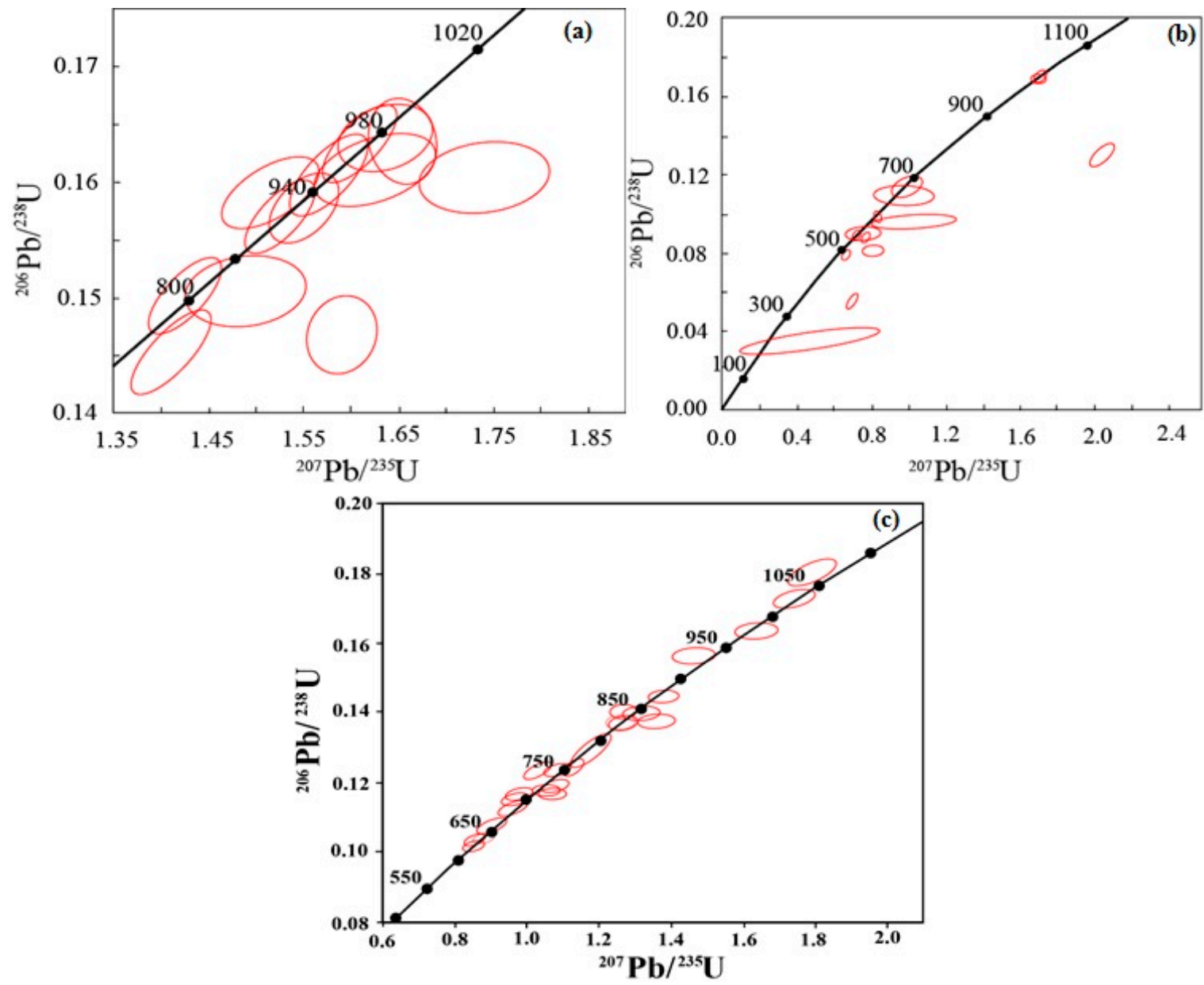

Figure 6. U-Pb zircon concordia plot and age determination for (a) Araru black to whitish gneiss; (b) from Araru whitish-grey gneiss, and (c) from Mboifong migmatite.

\subsection{U-Pb Zircon Age for Otu Granitic Pegmatite}

The U-Pb zircon ages for Otu granitic pegmatite are updated data, previously published in [5] (Figure 7a). The obtained ${ }^{206} \mathrm{~Pb} /{ }^{238} \mathrm{U}$ and ${ }^{207} \mathrm{~Pb} /{ }^{235} \mathrm{U}$ ages in the core of zircon crystals from this rock vary from $537 \pm 8.6$ to $639 \pm 25 \mathrm{Ma}$ and $546 \pm 7.2$ to $653 \pm 29 \mathrm{Ma}$, respectively. These ages date Mid Neoproterozoic (Cryogenian), Late Neoproterozoic, and 
Early Cambrian crystallization events. Those obtained rim ages for the same crystals vary from $506 \pm 11$ to $589 \pm 11 \mathrm{Ma}$ and $490 \pm 13$ to $574 \pm 11 \mathrm{Ma}$, respectively. These ages are dated as Late Neoproterozoic and Early to Late Cambrian events.
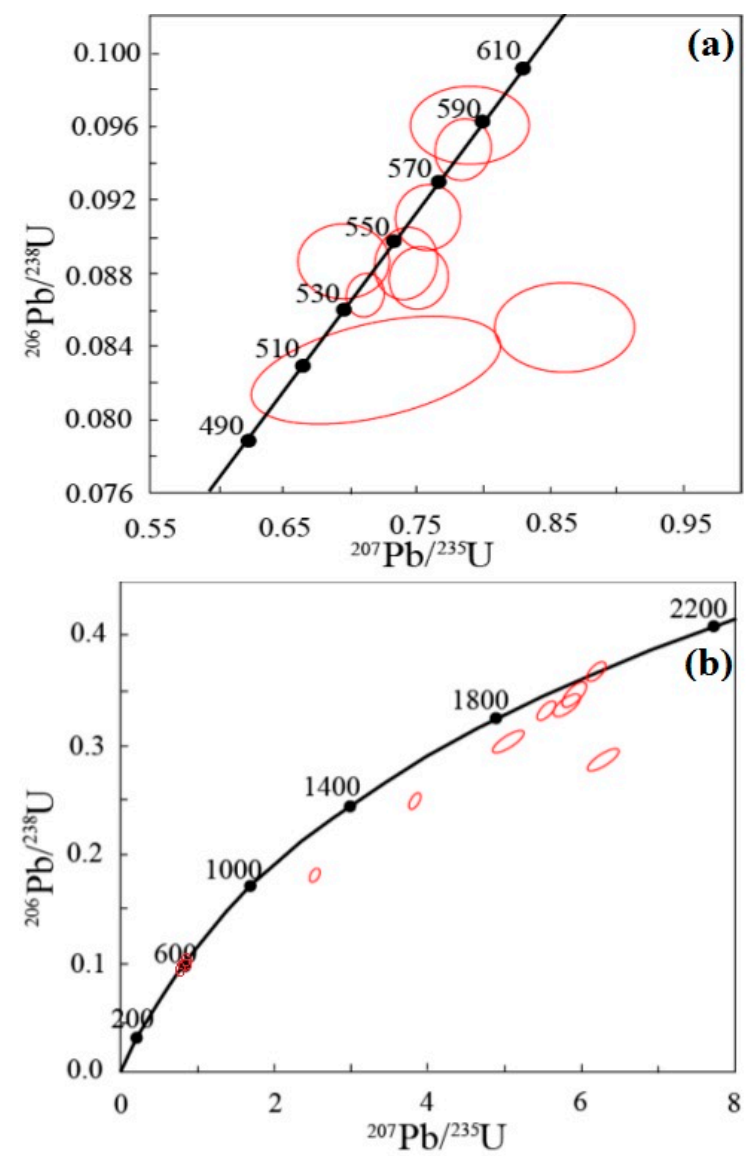

Figure 7. U-Pb zircon concordia plot and age determination for (a) Otu granitic pegmatite and (b) Babi mica schist (modified from [5]).

\subsection{U-Pb Zircon Age for Babi Mica Schist}

The U-Pb zircon ages for Babi mica schist are updated from previously published data [5] (Figure 7b). The obtained ${ }^{206} \mathrm{~Pb} /{ }^{238} \mathrm{U}$ and ${ }^{207} \mathrm{~Pb} /{ }^{235} \mathrm{U}$ ages in the core of zircon crystals from this rock vary from $562 \pm 12$ to $2019 \pm 30 \mathrm{Ma}$ and $544 \pm 13 \mathrm{Ma}$ to $2008 \pm 18 \mathrm{Ma}$, respectively. These ages date Mid to Late Paleoproterozoic and Late Neoproterozoic crystallization events. The rim ages for the zircons range from $543 \pm 12$ to $1919 \pm 36 \mathrm{Ma}$ and $526 \pm 12$ to $1954 \pm 20$ Ma. They date Mid Paleoproterozoic (Ordovician), Late Mesoproterozoic to Early Neoproterozoic, and Late Neoproterozoic to Early Cambrian events.

\subsection{U-Pb Zircon Ages for Nkogho I-Type Anatectic Granite}

The U-Pb zircon ages for Nkogho anatectic granite are updated from data published in [6] (Figure 8). The obtained ${ }^{206} \mathrm{~Pb} /{ }^{238} \mathrm{U}$ and ${ }^{207} \mathrm{~Pb} /{ }^{235} \mathrm{U}$ ages in the core of zircon crystals from this rock vary from $122 \pm 7.0$ to $989 \pm 19 \mathrm{Ma}$ and $115 \pm 6$ to $983 \pm 54 \mathrm{Ma}$. These ages date Early Neoproterozoic, Mid Neoproterozoic, Late Neoproterozoic, Late Cambrian, Middle Ordovician, and Aptian crystallizations with the predominance of zircon crystals crystallized during Late Neoproterozoic (Ediacaran) times. The obtained ages for other spots and rims range from $112 \pm 2.6$ to $620.6 \pm 9.9 \mathrm{Ma}$ and $108 \pm 1.7$ to $632.4 \pm 7.1 \mathrm{Ma}$, respectively. These ages date Late Neoproterozoic, Late Cambrian, Mid Ordovician, Mid to Late Devonian, Carboniferous, and Albian events. 


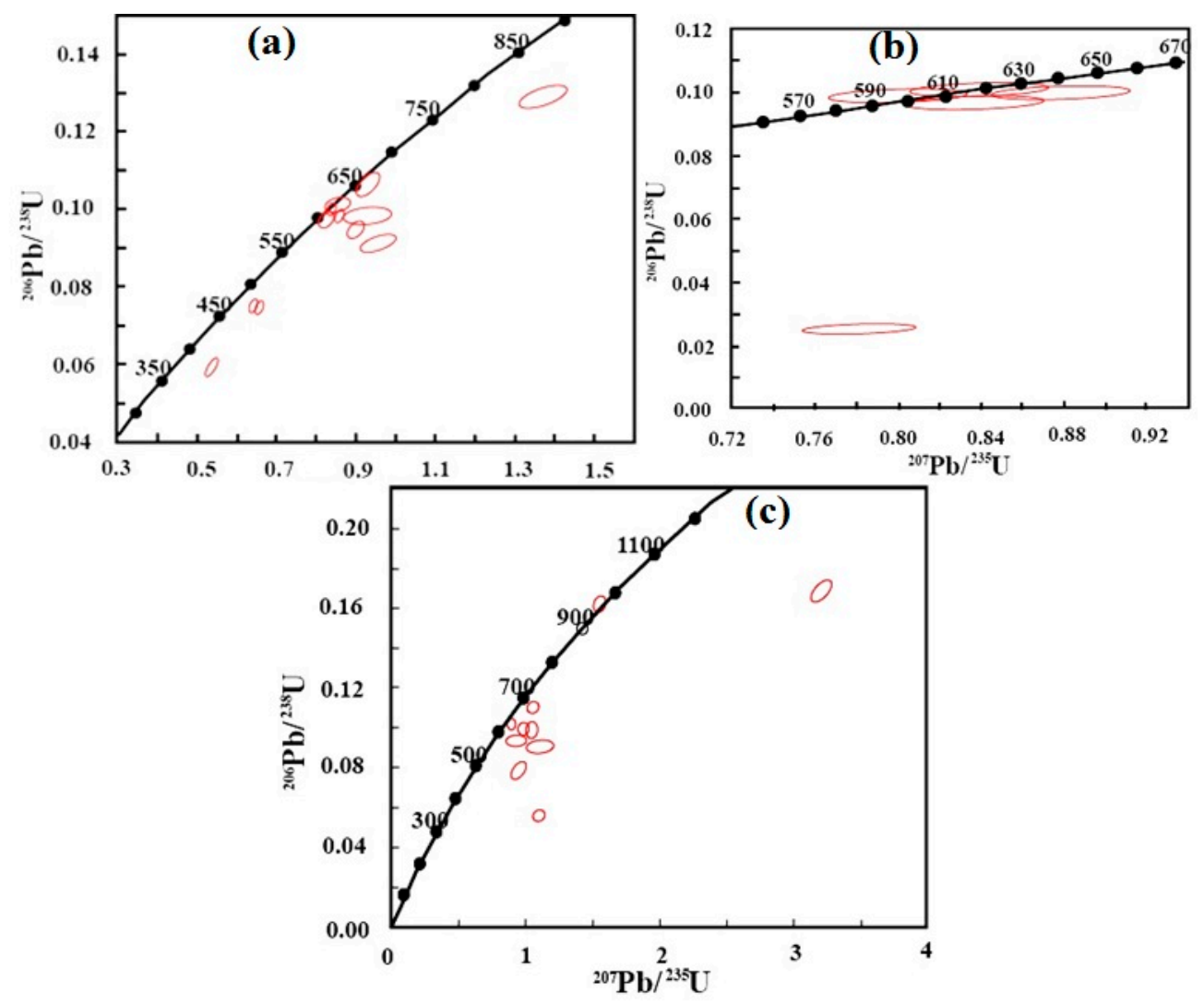

Figure 8. U-Pb zircon concordia plot and age determination for Nkogho I-type anatectic granite (modified from [5]).

\section{Discussion}

The obtained morphological, internal texture, U-Th-Pb composition, and U-Pb age data for zircon crystals from Araru black to whitish gneiss, Araru whitish-grey gneiss, and Mboifong migmatite are distinctively used to characterize and elucidate the formation conditions of each crystal. These data are used to reconstitute pre- to-post formation histories recorded by their host rock. For a local and regional reconstitution, the obtained $\mathrm{U}-\mathrm{Pb}$ ages are coupled with those published for other basement rocks outcropping in the Mamfe Basin, which were updated in this manuscript. They are at the end compared to those of basement rocks in SE Nigeria and in the NE part of Brazil for correlation and a large-scale regional reconstitution.

6.1. Characteristics and Crystallization History of the Zircons from the Araru Gneisses and Mboifong Migmatite

6.1.1. Zircon Crystals from Black to Whitish Gneiss

Zircon crystals from black to whitish gneiss (Figure 3) show morphological, textural, $\mathrm{U}-\mathrm{Th}-\mathrm{Pb}$ compositional, and $\mathrm{U}-\mathrm{Pb}$ age differences, with the most pronounced being that of $\mathrm{U}-\mathrm{Th}-\mathrm{Pb}$ abundance. These differences may reflect their crystallization history, thus fingerprinting these events. The grain size is dominantly greater than $100 \mu \mathrm{m}$; the crystal shape is dominantly euhedral (prismatic, pyramidal to dipyramidal), and few crystals are equant. These features are likely those of igneous zircons, as previously described $[5,6,19,31,124]$. Equant zircons could be crystals formed in deep-seated, slowly cooled intrusions, as this zircon type is common in these types of rocks (cf. [31]). The igneous nature of those zircons is supported texturally, as they show the predominance of growth zoning, classified as crustal magmatic features related to differentiation (cf. [31]). Part of the zircon encloses a xenocrystic core (xenocrystic zircons), which characterize features of zircons in magmatic or high-grade metamorphic rocks. Few crystals show a disrupted concentric oscillatory zoning, representing a recrystallizing feature that modified the magmatic zircons during 
late- and post-magmatic cooling (cf. [31]); this probably occurred in deep-seated settings (e.g., $[30,125])$. The presence of a bulbous replacement, and few microcracks in some zircons, seem to show medium- to high-temperature metamorphism (cf. [126]) or features formed during post-emplacement tectonic fracturing. Zircon fragments within the zircon population are slightly broken crystals from post-emplacement tectonic fracturing. The sub-rounding of very few grains may be of metamorphic origin.

The $\mathrm{U}, \mathrm{Th}$, and $\mathrm{Pb}$ contents and $\mathrm{Th} / \mathrm{U}$ ratios, which were used to characterize zircon crystals and understand their crystallization conditions (e.g., $[19,31,32,34,35,124,127])$ in zircons, are heterogeneous; this could reflect another phase of crystallization. The $\mathrm{U}$ (42-131 ppm), Th (41-189 ppm), and $\mathrm{Pb}$ (19-82 ppm) contents show considerable variation due to their formation environment. The $\mathrm{U}$ and Th contents, in particular, are largely above the value of mantle zircons $(\mathrm{U}<30 \mathrm{ppm}$ and $\mathrm{Th}<10 \mathrm{ppm})[127,128]$. This suggests a crustal origin for those zircons. The Th/U ratios (0.93-1.49) are within the values pointing to a magmatic origin of these zircons $(>0.4$ and $>1.0)$, similar to earlier research $[19,34,35]$; they can, therefore, be classified as crustal magmatic zircons. The Th/U ratios are greater than the average values (0.4 in granitic zircon [129]) and (1.0 in felsic magmatic zircons [128]).

The heterogeneous core $\mathrm{U}-\mathrm{Pb}$ ages $\left({ }^{206} \mathrm{~Pb} /{ }^{238} \mathrm{U} 875 \pm 14\right.$ to $976 \pm 15 \mathrm{Ma}$ and ${ }^{207} \mathrm{~Pb} /{ }^{235} \mathrm{U}$ $891 \pm 15$ to $971 \pm 13 \mathrm{Ma}$ ) date to Early Neoproterozoic (Tonian) crystallization events. This shows that the studied zircons were crystallized at different times during the Early Neoproterozoic period, representing zircon crystals crystallized from a crustal felsic granitic magma during Early Neoproterozoic times. Part of these ages are close to Early Neoproterozoic age (933 and $954 \mathrm{Ma}$ ) for xenocrystic zircons found in Nkogho anatectic granite [6] and dating inheritance. They could also date Early Neoproterozoic inheritance, as most of the ages were obtained in the analyzed xenocrystic cores. Overgrowth domains were not dated, so it was not possible to evaluate recorded post crystallization events.

\subsubsection{Zircon Crystals from Whitish-Grey Gneiss}

The whitish-grey gneiss grain sizes analyzed were greater than $100 \mu \mathrm{m}$. The crystals show different shapes that may characterize a variety of environments of crystallization and other disturbance events. Some crystals show features of magmatic crystallization (xenocrystic core, unzoned and zoned prismatic, and pyramidal to dipyramidal zircons) and metamorphic zircons (subrounded soccer ball-shape) similar to those described earlier $[5,19,31]$. Part of the study reveals zircons exhibiting post-crystallization features (preserved core surrounded by newly growth domains, local recrystallization, and convolute zoning) which for $[31,130]$ can represent progressive magmatic events or post emplacement metamorphism.

The $\mathrm{U}, \mathrm{Th}$, and $\mathrm{Pb}$ contents and $\mathrm{Th} / \mathrm{U}$ ratios show an extreme variation from one spot to another in the same zircon crystal, with some spots enclosing relatively high contents of those elements. This variation is found in both core and growth domains and led to the distinction of three groups of spots (1) spots with relatively high U-Th contents; (2) spots with relatively high $U$ contents and low Th content; and (3) spots showing relatively low U-Th contents. The high U-Th contents in some spots can relate to their crystallization (for cores), or growth (growth domains) in U-Th enriched melts with favorable conditions for $\mathrm{Zr}$ to be substituted by $\mathrm{U}$ and $\mathrm{Th}$. The relatively high $\mathrm{U}$ contents and low $\mathrm{Th}$, in group two, can be approached in two ways (1) the spotted area crystallized or grew in a setting enriched in U, although Th-depleted; and (2) the spotted area crystallized or grew in an environment enriched in $\mathrm{U}$ and $\mathrm{Th}$ with a lack of favorable conditions to facilitate $\mathrm{Th}-\mathrm{Zr}$ substitutions. The crystallization of a Th-bearing mineral (e.g., monazite) in a cooling melt can negatively impact the Th-Zr substitutions, as most of the Th will preferentially associate with $\mathrm{P}$ to form monazite and (or) allanite, rather than substituting for $\mathrm{Zr}$ in zircon (cf [19]). The relatively low $\mathrm{U}$ and low Th contents in group three show that the spotted zones were lightly crystallized or grown in a U-Th depleted environment or U-Th enriched melts with a lack of $\mathrm{u}$ conditions for $\mathrm{U}$ and $\mathrm{Th}$ to substitute for $\mathrm{Zr}$. The Pb contents $(0.06-135 \mathrm{ppm}$ and most $<30 \mathrm{ppm})$ may reflect crystallization or growth in dominantly 
low $\mathrm{Pb}$ melts and with probably low or lack of $\mathrm{U}$ and Th to enrich the spotted areas with daughter $\mathrm{Pb}$. Low $\mathrm{Pb}$ growth zones (with very low Th contents) may be recrystallized zones (see CL images, Figure 4), as recrystallized zones are often Th-Pb depleted [19]. The relatively high $\mathrm{Pb}$ contents in some spots can be due to the presence of radiogenic $\mathrm{Pb}$ from significant radioactive decay and non-radiogenic common $\mathrm{Pb}$ concentrations. It can also be interpreted by the loss of $\mathrm{Pb}$ during recrystallization, as growth recrystallization in some cases is combined with Pb-loss in granulite facies metamorphism (e.g., [3,131]). The $\mathrm{U}$ and Th contents are largely greater than the values presented $[127,128]$ for mantle source zircons. They are, therefore, zircons crystallized from crustal magmas. The calculated Th/U ratios $(0.007-2.156)$ are based on $[5,11,23,24]$, which show predominantly core and growth zones with metamorphic affiliations (with Th/U ratios $<0.07$ ) and a few crystallized magmatic or growth areas (with $\mathrm{Th} / \mathrm{U}$ ratios ranging from 0.86 to 2.16). The studied zircons are therefore composed of (1) zircons with a magmatic or metamorphic core and (2) zircons with magmatic or metamorphic growth zones.

The obtained zircon U-Pb ages $\left({ }^{206} \mathrm{~Pb} /{ }^{238} \mathrm{U} 212 \pm 11\right.$ to $1006 \pm 14 \mathrm{Ma}$ and ${ }^{207} \mathrm{~Pb} /{ }^{235} \mathrm{U}$ $213 \pm 14$ to $1005 \pm 9.1 \mathrm{Ma}$, Table 3) show an extreme variation that suggests different crystallization and growth histories in Early Neoproterozoic, Mid Neoproterozoic, Late Neoproterozoic, Early Carboniferous, and Late Triassic times. The oldest age ( 1005 Ma, with magmatic $\mathrm{Th} / \mathrm{U}>0.8$ ) recorded in the core (AR2-5R1) of zircon (14) dates to an Early Neoproterozoic (Tonian) crustal magmatic crystallization. This same zircon hosts overgrowth zones with different ages and Th/U ratios; the magmatic AR2-5C ( $999 \mathrm{Ma}$ and $\mathrm{Th} / \mathrm{U}=0.907)$ and the metamorphic AR2-5R2 (674 Ma and Th/U = 0.005). The magmatic nature of the oldest overgrowth Early Neoproterozoic zone (close to the core age) on this zircon shows that this zone was formed when the zircon-host melt was still magmatic, suggesting a progressive cooling of magma. Most outer growth zones (Mid Neoproterozoic and metamorphic in nature) show that these zones grew during Mid Neoproterozoic times; this represents a Mid Neoproterozoic (Cryogenian) metamorphic recrystallized feature. Another Mid Neoproterozoic age $\left({ }^{206} \mathrm{~Pb} /{ }^{238} \mathrm{U} 740 \mathrm{Ma}\right.$ and $\left.{ }^{207} \mathrm{~Pb} /{ }^{235} \mathrm{U} 685 \mathrm{Ma}\right)$ was obtained in zircon (24) (spot AR2-7-R). This zircon's U (134.2 ppm), Th (289.8 ppm), and Th/U (2.16 ppm) are within the range limit of crustal magmatic zircons $[5,6,19,23]$, and therefore show crystallization of a crustal magma, different to that of the Cryogenian metamorphic recrystallization zone (AR2-5R2) found in zircon (14). Consequently, the 740 to $685 \mathrm{Ma}$ zircon could be an inherited grain.

Late Neoproterozoic $\left({ }^{206} \mathrm{~Pb} /{ }^{238} \mathrm{U} 544-616 \mathrm{Ma}\right.$ and $\left.{ }^{207} \mathrm{~Pb} /{ }^{235} \mathrm{U} 547-618 \mathrm{Ma}\right)$ ages obtained in part of the studied zircons show that they registered Ediacaran events of three different periods (Early Ediacaran 605-617 Ma, Mid Ediacaran 571-579 Ma, and Late Ediacaran 498-554 Ma). The Th/U ratios in their spotted areas are dominantly $(<0.07)$ compatible with values in metamorphic zircons (see [5,11,23]). They largely represent metamorphic zircons crystallized and recrystallized during Ediacaran times. The oldest ages (605-617 Ma) represent Early Ediacaran syn-genetic metamorphic crystallization, as the zircons do not show any textural variation (no xenocrystic core and growth domains). The Mid Ediacaran age (573-579 Ma: AR2-4-C) was obtained in a zircon whose morphology, texture, U-Th compositions, and Th/U ratios show magmatic signatures; a magmatic nature of cooling during the Mid Ediacaran time can be suggested. Late Ediacaran ages (544-554 Ma) dominantly date recrystallized metamorphic portions in zircon (with $\mathrm{Th} / \mathrm{U}<0.04$ ); this shows that the studied zircon recorded a Late Ediacaran age. Metamorphic events were also evident in the Early Carboniferous to Triassic time, as one analyzed metamorphic zircon crystal showed these ages.

\subsubsection{Zircon Crystals from Mboifong Migmatite}

The obtained zircon $\mathrm{U}-\mathrm{Pb}$ ages $\left({ }^{206} \mathrm{~Pb} /{ }^{238} \mathrm{U} 623 \pm 5 \mathrm{Ma}\right.$ to $1068 \pm 15 \mathrm{Ma}$, and ${ }^{207} \mathrm{~Pb} /{ }^{235} \mathrm{U} 624 \pm 9.7$ to $1040 \pm 18 \mathrm{Ma}$; Table 4) predominantly show Mid Neoproterozoic time with few spots showing Early and Late Neoproterozoic, and Late Mesoproterozoic times. The predominant Mid Neoproterozoic age spots and their magmatic nature 
(Th/U $>0.3$, feature for magmatic zircons [6,35]) show that they were mostly formed in magmatic melts during this period (subdivided into 830-849 $\mathrm{Ma}, 701-787 \mathrm{Ma}$, and 637-673 Ma). This can suggest a progressive crystallization in a crustal magmatic melt during Mid Neoproterozoic time. The few Late Mesoproterozoic and Early Neoproterozoic magmatic spots in the core of some crystals may show inheritance. The Th/U ratios (0.003-0.121, a metamorphic-anatectic signature [6,11,23,32]) in few Mid to Late Neoproterozoic spots show that their host zircons registered Mid to Late Neoproterozoic anatectic-metamorphic events (crystallization and recrystallization). The magmatic nature $(\mathrm{Th} / \mathrm{U}>0.3)$ of part of the recrystallized portions may be due to their formation in magmatically derived aqueous fluids, as proposed by [30,125]. The metamorphic nature of part of the recrystallized portions suggests a Late Cryogenian recrystallization in a metamorphic melt with a loss of $\mathrm{Pb}$ see [126], as this spot (MBF5R2) shows very low $\mathrm{Pb}$ (11.1 ppm).

\subsection{Host Rocks Formation History and Registered Post-Emplacement Events with Local Correlations}

The combination of interpretations on zircon morphological and internal textural data, U-Th, Th/U features, and U-Pb ages presented in the above paragraphs will help to propose a formation model for the black to whitish gneiss, whitish-grey gneiss, Mboifong migmatite, and present registered crystallization events within the local setting.

\subsubsection{Araru Black to Whitish Gneiss}

The plotted dates in Figure 6a point to three main concordia ages (900 Ma, Late Tonian; $940 \mathrm{Ma}$, Mid Tonian; and $980 \mathrm{Ma}$, Early Tonian). It is suggested that the formation of the black to whitish gneiss took place progressively from Early to Late Tonian time. The crustal magmatic nature of the dated zircons shows that the black to whitish gneiss was formed from the crystallization of magmatic melt, probably from the partial fusion of an igneous protolith. The zircon Th/U ratios presented in the paragraphs above show a crustal granitic affinity, suggesting that the studied rocks were formed from a granitic protolith and, therefore, represents a Tonian age granitic orthogneiss. This rock can be older than other studied basement rocks (Otu granitic pegmatite, Babi mica schist, and I-type anatectic granite), outcropping in the Mamfe Sedimentary Basin (see Table 5). The Tonian ages are more than the Ediacaran to Cambrian ages registered by the Otu granitic pegmatite found in the SSW of the Mamfe Basin [5]; this shows that the black to whitish gneiss was formed earlier than the Otu granitic pegmatite. The tectonic magmatic events source the Otu granitic pegmatite probably did not affect the black to whitish gneiss, as no Ediacaran to Cambrian ages dating zircon core or growth zones were obtained. These Tonian ages are also more than the youngest concordia ages (Ediacaran) recorded in the Babi mica schist, dating the PanAfrican orogenic events [5]; this evidence indicates that the Tonian ages of black to whitish gneiss were emplaced before this Ediacaran PanAfrican orogeny. At this stage, it is not easy to know if the black to whitish gneiss recorded this orogenic event, as no syngenetic Ediacaran crystallized core and overgrowth recrystallized zone were dated. The Early-to-Mid Tonian concordia ages obtained in the black to whitish gneiss are very close to the core and crack ages ( 933 to $989 \mathrm{Ma})$ in two xenocrystic zircons from the Nkogho I type anatectic granite [6]. This similarity in age shows that the studied Early-to-Mid Tonian zircons and those from the Nkogho I-type anatectic granite were crystallized during the same period. It is not easy to confirm that these xenocryst zircons were sorted from the black to whitish gneiss, as the Th/U ratio $(<0.2)$ in the core of one zircon shows more anatectic affinity, one magmatic core with Th/U ratio (1.22), and that of the crack show closeness (see [6]). 


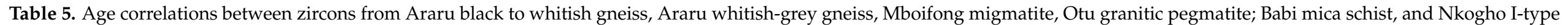
anatectic granite and Nkogho I-type anatectic granite, rocks SW Cameroon mobile belt, basement rocks in SE Nigeria, and the Borborema Province in NE Brazil.

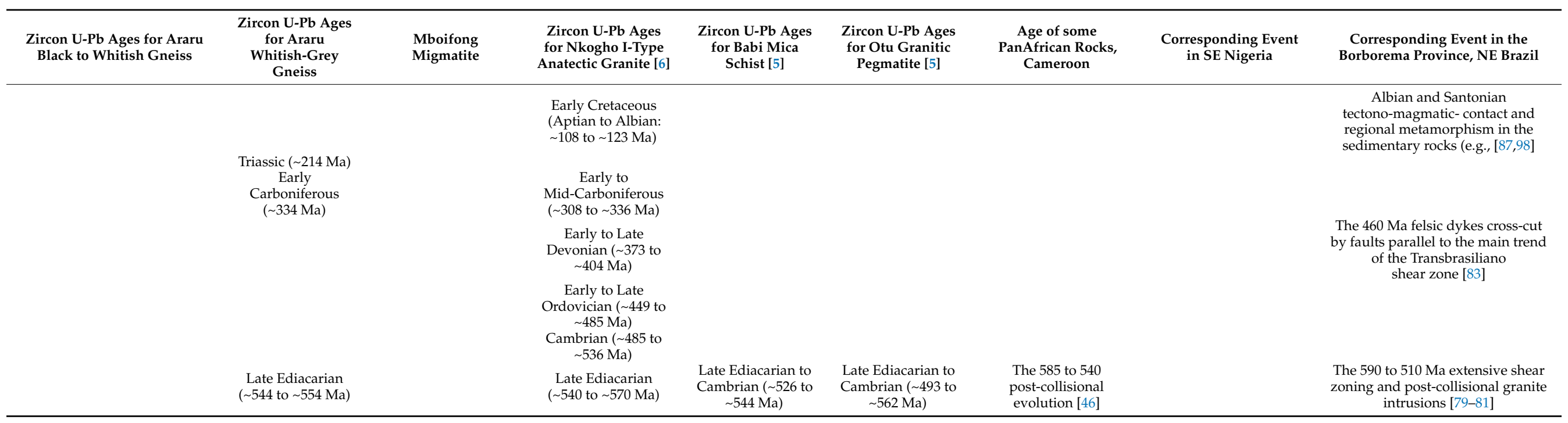


Table 5. Cont.

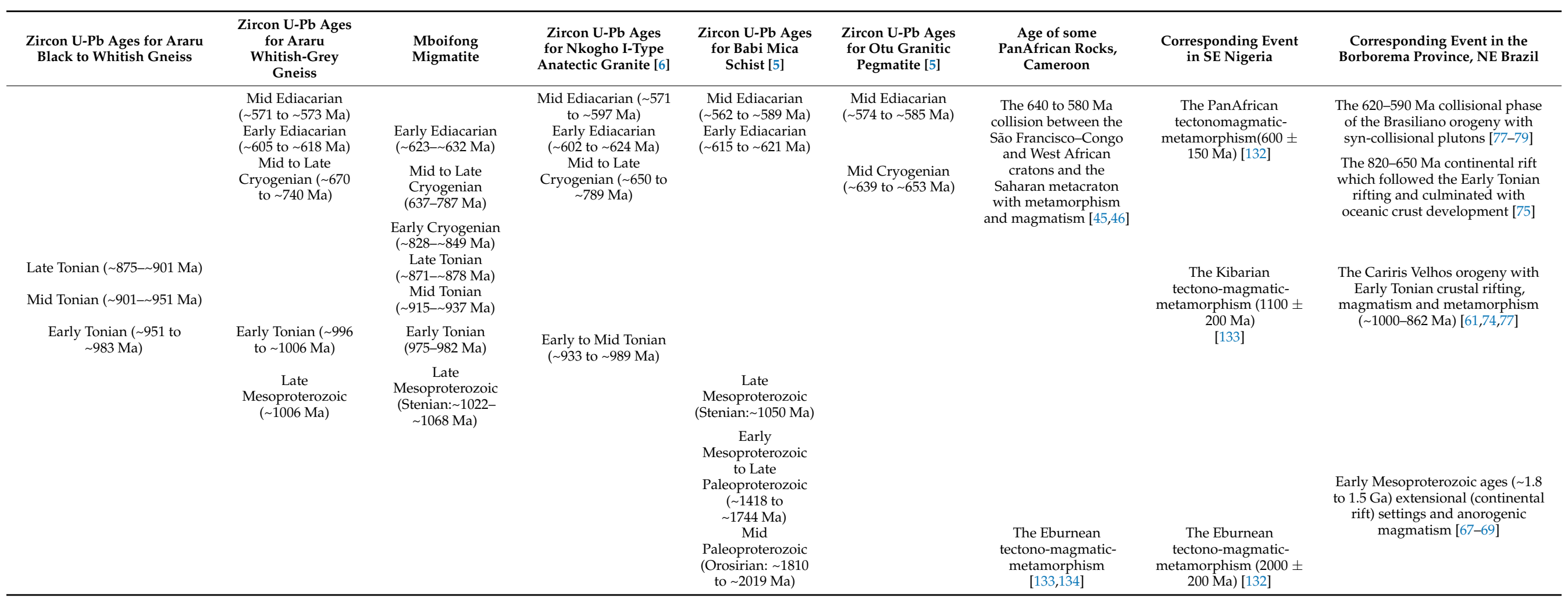




\subsubsection{Whitish-Grey Gneiss}

The plotted dates in Figure $6 \mathrm{~b}$ point to four main concordia ages, Stenian to Tonian, Cryogenian, Ediacaran, and Triassic. These ages could date four main geologic episodes: the Late Stenian to Early Tonian, Cryogenian, Ediacaran, and Triassic events. The Late Stenian to Early Tonian ages recorded in the core of a xenocrystic zircon could date inheritance; therefore, it was probably not crystallization in their host rock. The morphological feature, U-Th contents, and Th/U ratios presented in the above paragraphs show magmatic, clearly different from the metamorphic nature of its host rock, and support its inheritance. These ages are slightly older than Early Tonian ages obtained for zircon crystals from black to whitish gneiss (presented above) and for xenocrystic zircons from the Nkogho I-type anatectic granite presented in [6], but slightly younger than the Stenian age ( 1050 Ma) obtained for a metamorphic affiliated zircon occurring in the Babi mica schist (see [5]). This difference can complicate a local correlation and determination of the source rock and area of this Late Stenian to Early Tonian age xenocrystic zircon from the whitish-grey gneiss. It can be suggested that the studied Late Stenian to Early Tonian age xenocrystic zircon was crystallized slightly later than the Stenian metamorphic zircon found in Babi mica schists, but earlier than Early Tonian magmatic crystals found in black to whitish gneiss and Nkogho I-type anatectic granite during a Late Stenian to Early Tonian tectonic-magmatic/metamorphic event prior to the PanAfrican orogeny.

The Cryogenian ages may date the beginning of the formation of the whitish-grey gneiss, which probably ends in Ediacaran time. These Cryogenian ages are mainly close to those of zircon from the Nkogho I-type anatectic granite [6] (see Table 5). The magmatic nature of Mid to Late Cryogenian zircon from Nkogho I-type anatectic granite (see [6]), similar to that of a Mid Cryogenian zircon from the whitish-grey gneiss, show some closeness, but it is not easy to confirm any co-genesis. It can be suggested that the formation of the whitish-grey gneiss and Nkogho I-type anatectic granite began in Late Cryogenian time from different protoliths (sources): (1) partial melting of a pre-existing igneous arc-like granitic protolith for the Nkogho I-type anatectic granite (cf. [6]) and (2) metamorphic transformation of Early Tonian to Mid Cryogenian siliciclastic-rich sediments. These two events seem to have continued during the Mid Ediacaran. The metamorphic event source of the whitish-grey gneiss seems to have ended earlier (at Early Ediacaran) than that of the Nkogho I-type anatectic granite whose end-period should be Early Cambrian (cf. [6]), close to the end of final crystallization of the Otu granitic pegmatite and the formation of the Babi mica schist (cf. [5]).

Early Carboniferous and Triassic ages, respectively, recorded in the core and rim of a metamorphic zircon hosted by whitish-grey gneiss show their host rock was affected by a post-Ediacaran metamorphic event. This metamorphism is not yet mentioned in other studied basement rocks in the Mamfe Basin, although an Early Carboniferous magmatic age was obtained in the Nkogho I-type anatectic granite (see [6]). This closeness in age between the whitish-grey gneiss and the Nkogho I-type anatectic granite can be interpreted as follows; an Early Carboniferous crustal event simultaneously affected these rocks with a syngenetic crystallization of a metamorphic zircon in the whitish-grey gneiss, and syngenetic recrystallization of an Early to Mid-Carboniferous magmatic and metamorphic overgrowth zones on previously crystallized zircons. The Early Carboniferous crustal metamorphic transformation of the whitish-grey gneiss probably continued during the Triassic time, as this age was obtained in the rim of the same age zircon. For [37], the Mamfe Sedimentary Basin, the NW-SE segment of the NE-SW trending Benue Trough, started to form by rifting during the opening of the Gondwana supercontinent in the Triassic. The rift propagated along existing lines of weakness and broadened during early Jurassic times [37]. It was suggested that the rifting in the Mamfe Basin aborted in the Upper Albian to Lower Cenomanian [102] was due to the sub-crustal contraction and compression that led to the westward displacement of its depositional axis. Spreading ceased in the middle Jurassic, and as the lithosphere cooled, the shallow depression deepened [103]. 
The obtained Late Triassic zircon age for the whitish-grey gneiss could date the start of rifting and beginning of the formation of the Mamfe Basin (as presented by [37]), whose progression was registered during the early Jurassic times (cf. [37]), during Aptian to Albian times [6], or aborted in the Upper Albian to Lower Cenomanian [102]. This later information is just based on their approach [37]. The presence of Devonian to Carboniferous magmatism, anatexis, and related metamorphism recorded by zircon in the Nkogho I-type anatectic granite [6] and Araru whitish-grey gneiss show crustal reworking during those times and could date the start of the formation of the Mamfe Basin. It is therefore suggested that the formation of the Mamfe Basin began much earlier (Devonian to Carboniferous) than the Jurassic time, as proposed earlier [37].

\subsubsection{Mboifong Migmatite}

The plotted dates in Figure $6 \mathrm{c}$ points to four main concordia ages, Stenian (1022-1068 Ma), Tonian (871-982 Ma), Cryogenian (637-849 Ma), and Ediacaran (623-632 Ma). These ages could date four geologic episodes, Stenian to Tonian crystallization of the oldest zircons, Cryogenian formation of the protolith of the Mboifong migmatite from progressive cooling a crustal magma, and Late Cryogenian to Early Ediacaran partial fusion and metamorphism of the igneous protolith. The Stenian ages are more than the oldest age of analyzed spots on zircons from Araru whitish-grey gneiss, and below to greater the only Stenian age obtained in one analyzed spot in zircons from Babi mica schist. Tonian ages of zircons from Mboifong migmatite are also obtained mainly in zircons from Araru black to whitish gneiss and Nkogho I-type anatectic granite, showing that those three rocks registered a magmatic event during Tonian time. Zircons from Mboifong migmatite also show closeness in age with Cryogenian and Early Ediacaran analyzed spots on zircons from other rocks within the local geological setting (notably in zircons from Araru whitish-grey gneiss, Nkogho I-type anatectic granite, and Babi mica schist). These similarities show that parts of the zircons found in those rocks were crystallized, grew, or recrystallized at the same time.

\subsection{Regional Approach with the Cameroon Mobile Belt, SE of Nigeria and NE of Brazil}

The obtained and discussed data above for Araru black to whitish gneiss, Araru whitish-grey gneiss, Mboifong migmatite, Nkogho I-type anatectic granite, Otu granitic pegmatite, and Babi mica schist are compared with those available data for some rocks in part of the PanAfrican domain of Western Central Cameroon, in SE Nigeria and the Borborema Province (NE Brazil) for regional interpretation and approach on the preseparation of the South America and African plates.

\subsubsection{Rocks of the Cameroon Mobile Belt}

The Cameroon Mobile Belt or the PanAfrican Cameroon mobile belt is a mega tectonomagmatic/metamorphic feature enclosing many plutonic massifs and metamorphic rocks (emplaced following the extensive remobilization and granitization) during the collision between the São Francisco-Congo and West African cratons and the Saharan metacraton at 640 to $580 \mathrm{Ma}[45,46]$. Rocks in the various segments in the Cameroon Mobile Belt (West Cameroon, Central Cameroon, and South Cameroon) show variable ages, which make correlation difficult. Nevertheless, it is possible to attempt some correlations. In the West Cameroon Domain, an active margin is composed of 800 to $600 \mathrm{Ma}$ calc-alkaline NE-SW granitic intrusions $[52,59,134]$. The Central Cameroon domain is an intermediate continental domain and consists of PanAfrican granitoids intruding gneissic basement and emplaced in transpressional or transtensional fault relay zones [57]. The southern domain is made up of meta-sediments and pre- to syntectonic intrusions metamorphosed to granulite facies [135]. The obtained U-Pb zircon ages for Araru black to whitish gneiss, Araru whitishgrey, Mboifong migmatite, Nkogho I-type anatectic granite [6], Otu granitic pegmatite [5], and Babi mica schists [5] are compared those of some rocks in the West Cameroon Domain, which are close to the Mamfe Sedimentary Basin. The oldest ages are Mid Paleoproterozoic (Orosirian: 1810 to 2019 Ma), dated by inherited zircons from Babi mica schist [5], which 
correspond to the Eburnean tectono-magmatic/metamorphic events [134], recorded by $\sim 2.1$ Ga gneisses in the Kekem-Fotouni shear zone area [134], and amphibolite in Eseka (2000-2010 Ma, [135]). The Late Paleoproterozoic to Early Mesoproterozoic ages ( 1418 to $\sim 1744 \mathrm{Ma}$ ) enclose an inherited age in metasediment (1617 Ma) [49], some zircon core ages ( 1442 to $1743 \mathrm{Ma}$ ) in Dschang I-type high-K biotite granite, and ( 1629 Ma) in I-type high $\mathrm{K}$ magnetite granite that are suggested to form by partial melting of pre-existing igneous Paleoproterozoic protoliths [57]. These similarities of Late Paleoproterozoic to Early Mesoproterozoic occur in both the I-type high-K Dschang granites and the Babi mica schist. Closeness is also visible in Early Tonian to Cambrian zircon ages found in the I-type high-K Dschang granites, Babi mica schist, Araru black to whitish gneiss, Araru whitish-grey gneiss, Mboifong migmatite, Nkogho I-type anatectic granite, and/or Otu granitic pegmatite all show that zircons from those rocks registered similar events. In contrast, post-Cambrian ages found in zircons from some rocks in the Mamfe Basin were not obtained in the I-type high-K Dschang granites. They probably were not affected by those events.

\subsubsection{Links with Rocks in the SE Nigeria}

SE Nigeria (SW border of Cameroon) is separated from Cameroon by the Benue Trough a $1000 \mathrm{~km}$ NE-SW trending and 50 to $150 \mathrm{~km}$ wide mega tectonic, magmatic, and sedimentary structure (Figure 9) extending from the Niger Delta Basin to Lake Chad [87,98-100]. The youngest rocks (sedimentary, Cretaceous in age; and igneous, Jurassic to Cenozoic) found in the SE of Nigeria $[87,99,100]$, are associated with a Precambrian basement (named Nigerian shield or Nigeria basement complex) made up of gneisses, phyllites, schists, amphibolites, migmatites, and granites [136-138]. Rocks in this complex were affected by a polyphase tectono-metamorphic history, including Liberian $(2700 \pm 200 \mathrm{Ma})$, Eburnean (2000 $\pm 200 \mathrm{Ma})$, Kibarian (1100 $\pm 200 \mathrm{Ma})$, and PanAfrican $(600 \pm 150 \mathrm{Ma})$ events $[43,86,132,139]$. Part of these events were registered and dated by zircons in some basement rocks in the south to southwestern part of the Mamfe Basin. Notably, the Kibarian and PanAfrican events were fingerprinted by the Araru whitish-grey gneiss, Mboifong migmatite, Babi mica schist, Nkogho I-type anatectic granite, and/or Otu granitic pegmatite. The Kibarian tectonic event in the SSW of the Mamfe Basin probably led to the formation of Araru black to whitish gneiss, and the Babi mica schist; whereas, the PanAfrican event led to the formation of the Otu granitic pegmatite, Nkogho I-type anatectic granite, metamorphic transformation and reworking of Babi mica schist, Araru whitish-grey gneiss, and partial fusion and metamorphic transformation of the protolith of Mboifong migmatite.

Early Mesoproterozoic (1418 $\pm 18 \mathrm{Ma}$ and $1598 \pm 13 \mathrm{Ma})$ metamorphic zircons were found in the Babi mica schist, which is different to the Kibarian (1100 $\pm 200 \mathrm{Ma})$, presented above. It can be suggested that the Kibarian metamorphism started much earlier in Cameroon than in Nigeria. The other zircon ages available for rocks in the south to southwestern part of the Mamfe Basin are Late ( 1668 to 1744 Ma) to Mid Paleoproterozoic ( 1810 to $\sim 2019 \mathrm{Ma}$ ) found in the Babi mica schist. Although there is closeness with the Eburnean age presented above, it is difficult to confirm that their host rock was formed during these periods, as considered by the zircons to be inherited grains [5]. They could be grains sorted from rocks formed during Eburnean tectono-metamorphic/magmatic events found in a nearby or distant source (maybe in the Nigeria Basement Complex). 


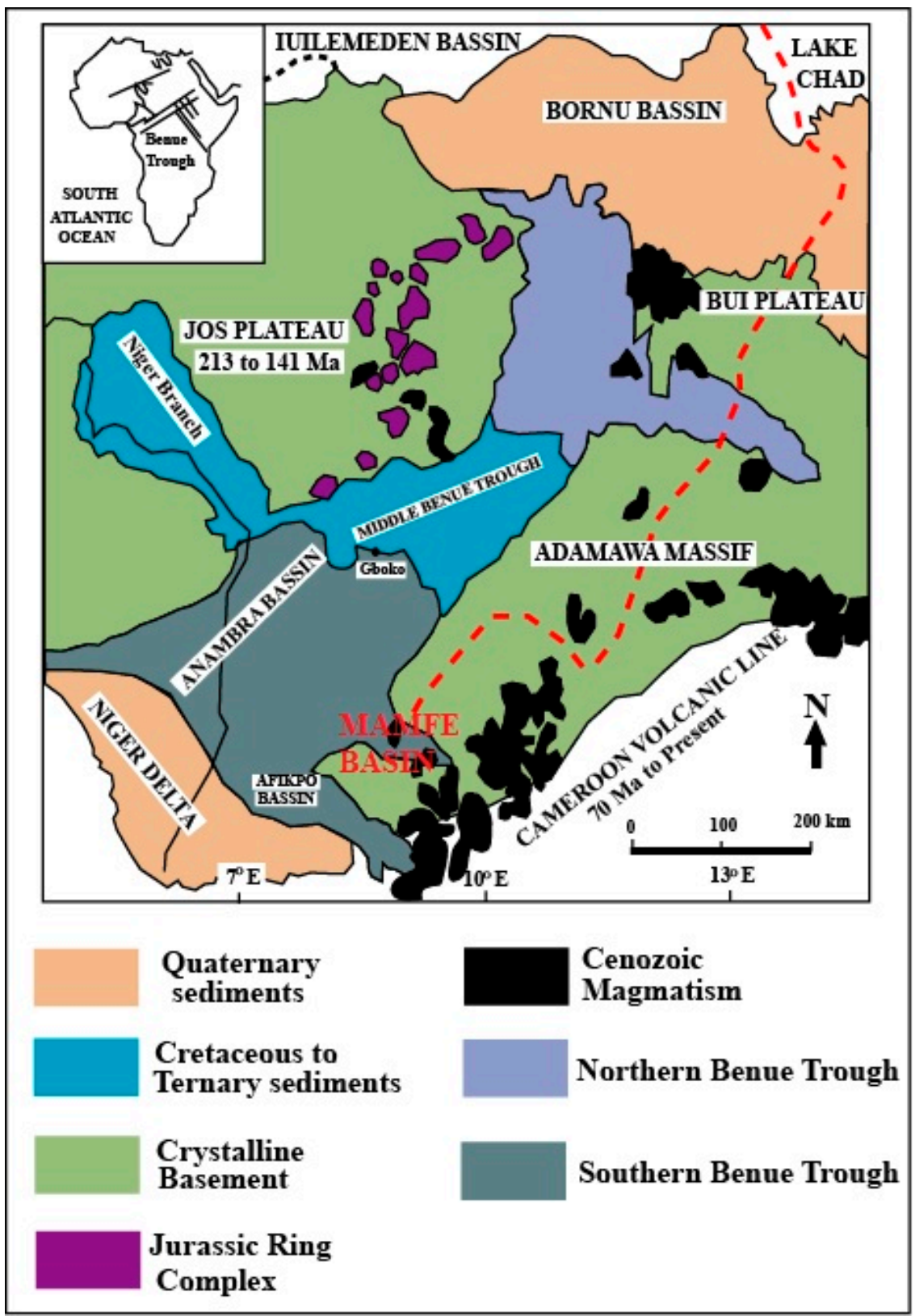

Figure 9. Geological sketch map of the Benue Trough (after [88]).

The Nigeria Basement Complex in its most east to southeastern part was also affected by post-PanAfrican crustal tectono-magmatic-sedimentary events [87,98,99], (1) the Jurassic crustal opening; (2) Cretaceous sedimentary infilling, Albian tectonism, low-grade regional contact metamorphism, Santonian tectonism, and low-grade regional metamorphism; and (3) the Jurassic to Cenozoic volcanism and plutonism. The youngest obtained U-Pb zircon ages found in Precambrian basement rocks in the south to southwestern parts of the Mamfe Sedimentary Basin (zircon from the Araru whitish-grey gneiss, and Nkogho I-type anatectic granite) show Ordovician to Devonian, Carboniferous to Triassic and/or Aptian to Albian. Most ages have not yet been published on Precambrian rocks within the Nigeria Basement Complex. Their absence can be interpreted in two ways, (1) those post-PanAfrican events never affected the basement rocks within the Nigeria Basement Complex or (2) the postPanAfrican events affected the basement rocks but have not yet been reported. Evidence was presented for Albian and Santonian tectono-magmatism and low-grade regional and contact metamorphism on the oldest Cretaceous sediments in the southeast of the Benue 
Trough [87]. However, he never confirmed that these tectono-magmatic/metamorphic events were fingerprinted by the Precambrian basements.

6.3.3. Links with Rocks in NE Brazil and Pre-Separation of the South American and African Plates

The Borborema Province in NE Brazil was built in the Neoproterozoic by agglutination of allochthonous lithospheric fragments during the Cariris Velhos ( 1000-920 Ma) and Brasiliano ( 625-510 Ma) orogenies. The U-Pb zircon ages obtained for black to whitish gneiss and whitish-grey gneiss in Araru, Mboifong migmatite, Nkogho I-type anatectic granite, Otu granitic pegmatite, and Babi mica schist show proximity with some rocks within the orogenic belt. The ages (1000 to $920 \mathrm{Ma}$ ) dating the Cariris Velhos orogeny in the Borborema Province in NE Brazil were registered by zircon crystals from whitish-grey gneiss with very thin bands ( 999 to $\sim 1006 \mathrm{Ma}$ ), black to whitish banded gneiss ( 901 to $\sim 983 \mathrm{Ma}$ ), Mboifong migmatite ( 915 to $\sim 1068 \mathrm{Ma}$ ), and Babi mica schist ( 1050 Ma). This closeness shows that the studied zircons registered the Cariris Velhos orogenic event with the formation of the black to whitish gneiss and Babi mica schist in the Mamfe Basin. This suggestion is possible since, in the Late Mesoproterozoic to Early Neoproterozoic, the South American and African Plates were still in contact (see Figure 10). Very old Mid Paleoproterozoic to Early Mesoproterozoic ( 2019 to $1418 \mathrm{Ma}$ ) rocks dated by most zircons exclusively in the Babi mica schist are mainly within the range limit $\sim .8$ to $1.5 \mathrm{Ma}$ in the Borborema Province (NE Brazil), corresponding to extensional settings with continental rifting and anorogenic magmatism [67-69]. More studies are still needed for further correlations. Mid Mesoproterozoic to Early Cambrian tectono-magmatic/metamorphic events registered in the Borborema Province (NE Brazil) were dated by studied rocks in the south to southwest Mamfe Basin. For example, (1) the Early Tonian crustal rifting with magmatism and metamorphism ( 1000-862 Ma) $[61,74,76]$ were registered by zircons in the oldest rocks in the south to southwest Mamfe Basin. (2) The 820-650 Ma continental drift that followed the Early Tonian rifting and culminated with oceanic crust development [75] was dated by zircons in Araru whitish-grey gneiss, Mboifong migmatite, Nkogho I-type anatectic granite and Otu granitic pegmatite. (3) The 620-590 Ma collisional phase of the Brasiliano orogeny with syn-collisional plutons $[75,77,78]$ was dated by zircons in Araru whitish-grey gneiss, Babi mica schist, Nkogho I-type anatectic granite, and Otu granitic pegmatite. (4) The 590 to 510 Ma extensive shear zoning and post-collisional granitic intrusions [75,79-81] were dated by zircons in the Araru whitish-grey, Babi mica schist, Nkogho I-type anatectic granite, and Otu granitic pegmatite. (5) The $460 \mathrm{Ma}$ felsic dykes cross-cut by faults parallel to the main trend of the Transbrasiliano shear zone [83] were exclusively dated by zircons in Nkogho I-type anatectic granite.

These correlations are still preliminary or subject to further investigation as more detailed research is still needed. Much younger ages (Early to Late Devonian $\sim 373$ to $\sim 404 \mathrm{Ma}$, Early to Mid-Carboniferous $\sim 308$ to $\sim 336 \mathrm{Ma}$, Triassic $\sim 214 \mathrm{Ma}$, and Early Cretaceous, Aptian to Albian $\sim 108$ to $\sim 123 \mathrm{Ma}$ ) were found for zircons in the old Precambrian basement rocks in the south to southwest Mamfe Basin. Additionally, their corresponding ages have not yet been reported in any published documents in the Borborema Province, although a Mid-Cretaceous age (U-Pb $135 \pm 4.7 \mathrm{Ma})$ dates calcite slickenfibres-bearing faults in shear zones bordering the Borborema Province orogenic belt [82]. It is probable that part of these events never affected the Borborema Province, as they could possibly have occurred at the beginning, during, and/or after the separation of the African plate from the South American plate (linked during the Precambrian times [39]) (Figure 10). 


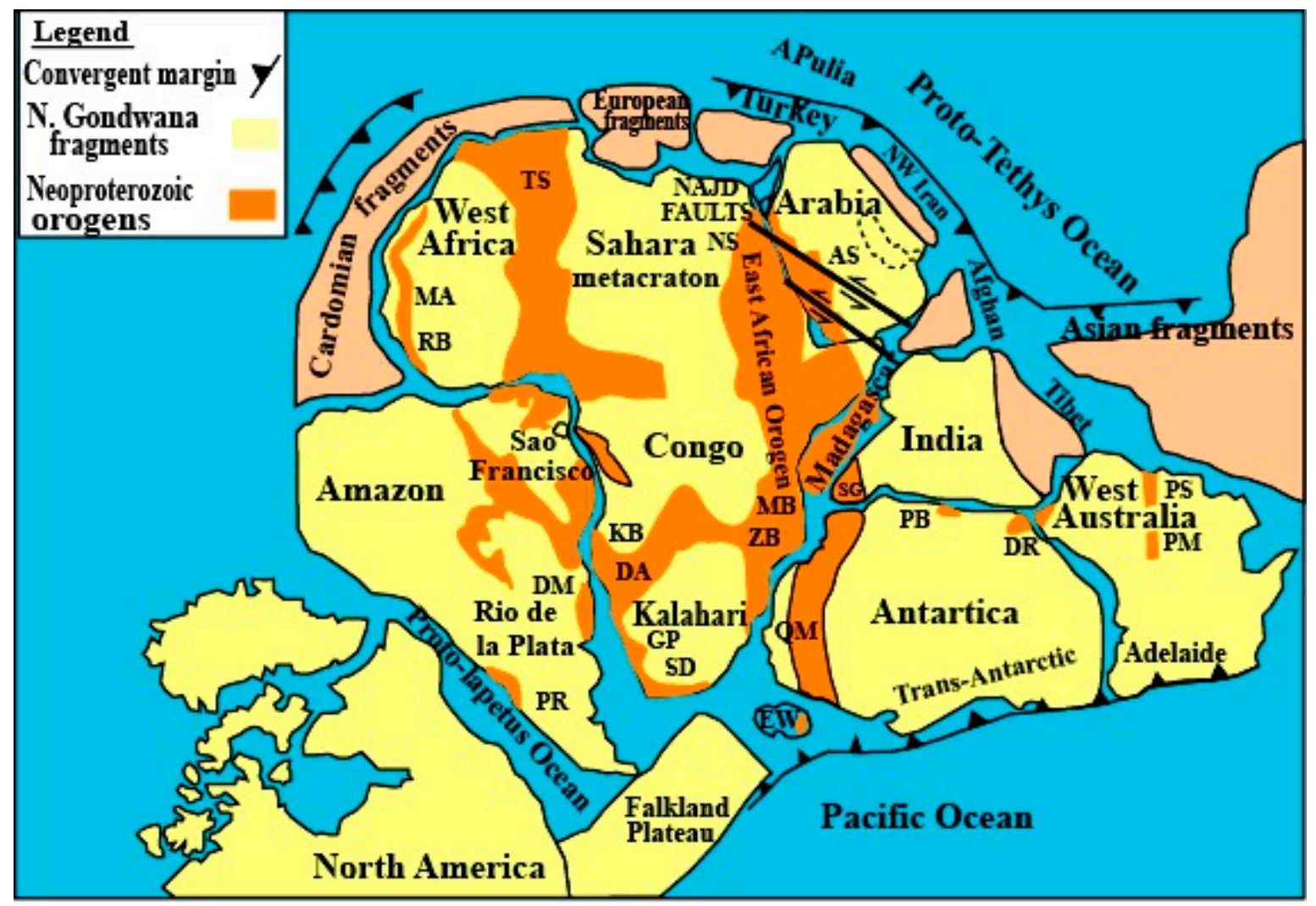

Figure 10. Map of Gondwana at the end of Neoproterozoic time (540 Ma) showing the general arrangement of PanAfrican belts. AS, Arabian Shield; BR, Brasiliano; DA, Darnara; DM, Dom Feliciano; DR, Denman Darling; EW, Ellsworth-Whitrnore Mountains; GP, Gariep; KB, Kaoko; MA, Mauretanides; MB, Mozarnbique Belt; NS, Nubian Shield; PM, Peterman Ranges; PB, Pryolz Bay; PR, Parnpean Ranges; PS, Paterson; QM, Queen Maud Land; RB, Rokelides; SD, Saldania; SG, Southern Granulite Terrane; TS, Trans-Sahara Belt; WB, West Congo; ZB, Zambezi. (Reproduced with permission from [140]).

\section{Conclusions}

The basement rocks of the Araru black to whitish gneiss, Araru whitish-grey gneiss, Mboifong migmatite, Nkogho I-type anatectic granite, Otu granitic pegmatite, and Babi mica schist in the south to southwestern part of the Mamfe Sedimentary Basin (SW Cameroon) belong to the PanAfrican mobile belts. They host zircon crystals that fingerprint the Mid Paleoproterozoic to Albian events with closeness to those of rocks in the SW Cameroon Mobile Belt, of SE Nigeria, and the Borborema Province, NE Brazil.

The oldest zircons are Mid Paleoproterozoic age, found in the Babi mica schist dating the Eburnean tectono-magmatic/metamorphic events in Cameroon and SE Nigeria. Coupled with the Early Mesoproterozoic ages, they correspond to the Late Paleoproterozoic to Early Mesoproterozoic ages extensional (continental rift) settings and anorogenic magmatism in the Borborema Province in the NE part of Brazil.

Late Mesoproterozoic to Early Neoproterozoic ages observed in zircons from the Araru black to whitish gneiss, Araru whitish-grey gneiss, Mboifong migmatite, Nkogho I-type anatectic granite, and Babi mica schist correspond to the Kibarian tectono-magmaticmetamorphism in SE Nigeria and the Cariris Velhos orogeny with Early Tonian crustal rifting, magmatism, and metamorphism in the Borborema Province in NE Brazil.

Mid to Late Cryogenian ages were found in zircons from the Araru whitish-grey gneiss, Mboifong migmatite, and Nkogho I-type anatectic granite, which probably date the beginning of collisional phases between the São Francisco-Congo and West African cratons and the Saharan metacraton with metamorphism and magmatism in Cameroon; this is also linked to the continental rift that followed the Early Tonian rifting, culminating 
with oceanic crustal development and subducted and continental arc phases enclosing the syn-orogenic phase in the Borborema Province in NE Brazil.

The Early to Late Cambrian zircon ages found in the Araru whitish-grey gneiss, Nkogho I-type anatectic granite, Babi mica schist, and the Otu granitic pegmatite, probably date the progress of the collisional phases between the São Francisco-Congo and West African cratons and the Saharan metacraton with metamorphism and magmatism, and post-collisional evolution in Cameroon. This relates the PanAfrican tectonomagmatic/metamorphism in SE Nigeria and the collisional phase of the Brasiliano orogeny, with syn-collisional plutons and extensive shearing and post-collisional granite intrusions in the Borborema Province in NE Brazil.

The Early Devonian to Early Cretaceous zircon ages for the Araru whitish-grey and Nkogho I-type anatectic granite were not found in any basement rocks in other parts of the Cameroon Mobile Belt, in SE Nigeria, or the Borborema Province in the NE part of Brazil. This suggests that zircons in the basement rocks found in the correlated megastructures probably never recorded those events.

Author Contributions: Conceptualization, K.S.N. and L.R.D.; methodology, Z.K.; software, B.A.A.E.; validation, L.R.D., Y.F.R. and N.E.; formal analysis, M.C.; investigation, K.S.N.; resources, L.R.D.; data curation, M.C.; writing — original draft preparation, K.S.N.; writing — review and editing, K.S.N. and L.R.D.; visualization, K.S.N.; supervision, Z.K.; project administration, K.S.N.; funding acquisition, L.R.D. All authors have read and agreed to the published version of the manuscript.

Funding: This research received no external funding.

Acknowledgments: The authors extend their gratitude to Zhenbing She from the China University of Geosciences in Wuhan for funding the BSE-CL imaging of the zircon crystals. Thanks to the laboratory personnel at the University of New Brunswick who carried out the U-Th analysis and dating of the zircon crystals. Professor David R. Lentz (UNB) was funded by a Natural Sciences and Engineering Research Council grant. Our gratitude to the anonymous reviewers whose useful comments helped to improve and deeply reworked the manuscript.

Conflicts of Interest: The authors declare no conflict of interest.

\section{References}

1. Paquette, L.J.; Menot, P.R.; Pin, C.; Orsini, B.J. Episodic and short-lived granitic pulses in a post-collisional setting: Evidence from precise U-Pb zircon dating through a crustal cross-section in Corsica. Chem. Geol. 2003, 198, 1-20. [CrossRef]

2. Aguilar, C.; Liesa, M.; Castiñeiras, P.; Navida, M. Pb age zircon dating-Pyrenees revealed by U-Pb Late Variscan metamorphic and magmatic evolution in the eastern. J. Geol. Soc. 2013, 171, 181-192. [CrossRef]

3. Kröner, A.; Wan, Y.; Liu, X.; Liu, D. Dating of zircon from high-grade rocks: Which is the most reliable method? Geosci. Front. 2014, 5, 515-523. [CrossRef]

4. Dawaï, D.; Bouchez, J.L.; Paquette, J.L.; Tchameni, R. The Pan-Afrcan quartz-syenite of Guider (North-Cameroon): Magnetic fabric and U-Pb dating of a late-orogenic emplacement. Precambrian Res. 2013, 236, 132-144. [CrossRef]

5. Kanouo, S.N.; Njonfang, E.; Kouské, P.A.; Yongue, F.R.; Ngueutchoua, G. U-Pb zircon age: Preliminary data evaluating the Earth history recorded by two basement rocks (granitic pegmatite and mica-schist) in Mamfe Basin (SW Cameroon, Central Africa). J. Geol. Geophys. 2017, 6, 1-9. [CrossRef]

6. Kanouo, S.N.; Kouské, P.A.; Lentz, R.D.; She, Z.; Yongue, F.R. New insights into Neoproterozoic-Cretaceous events in the Mamfe Basin (SW Cameroon, Central Africa): Evidence from textural analyses, U-Th composition, and U-Pb zircon geochronology from granitic basement. J. Earth Sci. 2021; Accepted proof.

7. Takashi, Y.; Kozue, I.; Shuhei, S.; Yokohama, T.; Itoh, D.; Ogita, Y.; Yagi, K.; Ohno, T. Simultaneous determination of zircon U-Pb age and titanium concentration using LA-ICP-MS for crystallization age and temperature. Lithos 2020, 372-373, 105682.

8. Larson, A.S.; Berglund, J.A. Chronological subdivision of the Transscandinavian Igneous Belt-Three magmatic episodes? Geol. Föreningen i Stockh. Förhandlingar 1992. [CrossRef]

9. Rubatto, D.; Gebauer, D.; Compagnoni, R. Dating of eclogite-facies zircons: The age of Alpine metamorphism in the Sesia-Lanzo Zone (Western Alps). Earth Planet. Sci. Lett. 1999, 167, 141-158. [CrossRef]

10. Rubatto, D.; Williams, I.S.; Buick, I.S. Zircon and monazite response to prograde metamorphism in the Reynolds Range, Central Australia. Contrib. Min. Petrol. 2001, 140, 458-468. [CrossRef]

11. Rubatto, D. Zircon trace element geochemistry: Partitioning with garnet and link between U-Pb ages and metamorphism. Chem. Geol. 2002, 184, 123-138. [CrossRef]

12. Rubatto, D. Zircon: The metamorphic mineral. Rev. Miner. Geochem. 2017, 83, 10-34. 
13. Rubatto, D.; Hermann, J. Experimental zircon/melt and zircon/garnet trace element partitioning and implications for the geochronology of crustal rocks. Chem. Geol. 2007, 241, 62-87. [CrossRef]

14. Xiao, L.L.; Chen, H.M. Metamorphic Age Comparison and Its Implications between the Zuoquan and Zanhuang Complexes in the Central North China Craton, Based on LA-ICP-MS Zircon U-Pb Dating. Minerals 2019, 9, 780. [CrossRef]

15. Pelleter, E.; Cheilletz, A.; Gasquet, D.; Mouttaqi, A.; Annich, M.; El Hakour, A.; Deloule, E.; Féraud, G. Hydrothermal zircons: A tool for ion microprobe U-Pb dating of gold mineralization (Tamlalt-Menhouhou gold deposit Morocco). Chem. Geol. 2007, 245, 135-161. [CrossRef]

16. Bao, Z.; Sun, W.; Li, C.; Zhao, Z. U-Pb dating of hydrothermal zircon from the Dongping gold deposit in North China: Constraints on the mineralization processes. Ore Geol. Rev. 2014, 61, 107-119. [CrossRef]

17. Deng, X.D.; Li, J.W.; Wen, G. U-Pb geochronology of hydrothermal zircons from the Early Cretaceous iron skarn deposits in the Handan-Xingtai District, North China Craton. Econ. Geol. 2015, 110, 2159-2180. [CrossRef]

18. Jiang, C.W.; Li, H.; Turner, S.; Zhu, D.P.; Wang, C. Timing and origin of multi-stage magmatism and related W-Mo-Pb-Zn-Fe-Cu mineralization in the Huangshaping deposit, South China: An integrated zircon study. Chem. Geol. 2020, 552, 119782. [CrossRef]

19. Hoskin, P.W.O.; Schaltegger, U. The composition of zircon and igneous and metamorphic petrogenesis. In Reviews in Mineralogy and Geochemistry; Mineralogical Society of America: Washington, DC, USA, 2003; Volume 53, pp. 27-55.

20. Xia, X.; Sun, M.; Zhao, G.; Luo, Y. LA-ICP-MS U-Pb geochronology of detrital zircons from the Jining Complex, North China Craton and its tectonic significance. Precambrian Res. 2006, 144, 199-212. [CrossRef]

21. Kanouo, S.N.; Zaw, K.; Yongue, F.R.; Sutherland, L.F.; Meffre, S.; Njonfang, E.; Ma, C.; Tchouatcha, S.T. U-Pb zircon age constraining the source and provenance of gem-bearing Late Cenozoic detrital deposit, Mamfe Basin, SW Cameroon. Resour. Geol. 2012, 62, 316-324.

22. Kanouo, S.N.; Yongue, F.R.; Ekomane, E.; Njonfang, E.; Ma, C.; Lentz, D.R.; She, Z.; Zaw, K.; Venkatesh, A.S. U-Pb ages for zircon grains from Nsanaragati Alluvial Gem Placers: Its correlation to the source rocks. Resour. Geol. 2015, 65, 103-121. [CrossRef]

23. Kanouo, S.N.; Ngueutchoua, G.; Kouske, P.A.; Yongue, F.R.; Venkatesh, A.S. Trace element and U-Pb core age for zircons from western Meiganga gold placer, Cameroon: Their genesis and Archean-Proterozoic sources. Minerals 2018, 8, 194. [CrossRef]

24. Kanouo, S.N.; Kouské, P.A.; Ngueutchoua, G.; Venkatesh, A.S.; Sahoo, R.P.; Basua, A.A.E. Eoarchean to Neoproterozoic detrital zircons from the south of Meiganga gold-bearing sediments (Adamawa, Cameroon): Their closeness with rocks of the PanAfrican Cameroon Mobile Belt and Congo Craton. Minerals 2021, 11, 77. [CrossRef]

25. Caxito, F.A.; Dantas, E.L.; Stevenson, R.; Uhlein, A. Detrital zircon (U-Pb) and Sm-Nd isotope studies of the provenance and tectonic setting of basins to collisional orogens: The case of the Rio Preto fold belt on the northwest SãoFrancisco Craton margin, NE Brazil. Gondwana Res. 2014, 26, 741-754. [CrossRef]

26. Cao, L.; Jiang, T.; Wang, Z.; Zhang, Y.; Sun, H. Provenance of Upper Miocene sediments in the Yinggehai and Qiongdongnan basins, northwestern South China Sea: Evidence from REE, heavy minerals and zircon U-Pb ages. Mar. Geol. 2015, 361, 136-146. [CrossRef]

27. Mbih, P.K.; Meffre, S.; Yongue, F.R.; Kanouo, S.N.; Jay, T. Chemistry and origin of the Mayo Kila sapphires, NW region Cameroon (Central Africa): Their possible relationship with the Cameroon volcanic line. J. Afr. Earth Sci. 2016, 118, 263-273. [CrossRef]

28. Andersen, T.; Kristoffersen, M.; Elburg, A.M. How far can we trust provenance and crustal evolution information from detrital zircons? A South African case study. Gondwana Res. 2016, 34, 129-148. [CrossRef]

29. Neves, P.S. Comparative geological evolution of the Borborema Province and Sao Francisco Craton (eastern Brazil): Decratonization and crustal reworking during West Gondwana assembly and implications for paleogeographic reconstructions. Precambrian Res. 2021, 355, 106116.

30. Schaltegger, U.; Fanning, M.C.; Gunther, D.; Maurin, C.J.; Schulmann, K.; Gauber, D. Growth, annealing and recrystallization of zircon and preservation of monazite in high-grade metamorphism: Conventional and in-situ U-Pb isotope, cathodoluminescence and microchemical evidence. Contrib. Miner. Petrol. 1999, 134, 186-201. [CrossRef]

31. Corfu, F.; Hanchar, J.M.; Hoskin, P.W.O.; Kinny, P. Atlas of zircon texture. In Reviews in Mineralogy and Geochemistry; Mineralogical Society of America: Washington, DC, USA, 2003; Volume 53, pp. 469-500.

32. Yakymchuk, C.; Kirkland, L.C.; Clark, C. Th/U ratios in metamorphic zircon. J. Metamor. Geol. 2018, 36, 715-737.

33. Yakymchuk, C.; Brown, M. Divergent behaviour of Th and U during anatexis: Implications for the thermal evolution of orogenic crust. J. Metamor. Geol. 2019, 37, 899-916. [CrossRef]

34. Belousova, A.E.; Griffin, L.W.; O’Reilly, Y.S.; Fisher, I.N. Igneous zircon: Trace element composition as an indicator of source rock type. J. Miner. Petrol. 2002, 143, 602-622. [CrossRef]

35. Kirkland, C.L.; Smithies, R.H.; Taylor, R.J.M.; Evans, N.; McDonald, B. Zircon Th/U ratios in magmatic environs. Lithos 2015, 212-215, 397-414. [CrossRef]

36. Wilson, D. Notes on the Geology of the Mamfe Division, Cameroon SW Province; Occasional Papers; Geologic Survey of Nigeria: Abuja, Nigeria, 1928.

37. Dumort, J.C. Carte Géologique de Reconnaissance du Cameroun à L'échelle 1/500000 Feuille Douala-Ouest, Avec Notice Explicative; Imprimerie Nationale: Yaoundé, Cameroon, 1968; p. 69.

38. Kanouo, S.N. Geology of the Western Mamfe Corundum Deposits, SW Region Cameroon: Petrography, Geochemistry, Geochronology, Genesis, and Origin. Ph.D. Thesis, University Yaoundé I, Yaoundé, Cameroon, 2014.

39. Kröner, A.; Stern, J.R. Pan-African Orogeny North African Phanerozoic rift valley. Encycl. Geol. 2005, 1, 1-12. 
40. Kwékam, M.; Liégeois, J.P.; Njonfang, E.; Affaton, P.; Hartmann, G.; Tchoua, F. Nature, origin, and significance of the Fomopéa Pan-African highK calc-alkaline plutonic complex in the Central African fold belt (Cameroon). J. Afr. Earth Sci. 2010, $54,79-95$. [CrossRef]

41. Lerouge, C.; Cocherie, A.; Toteu, F.S.; Penaye, J.; Mile, P.J.; Tchameni, R.; Nsifa, N.E.; Fanning, M.C.; Deloule, E. Shrimp U-Pb zircon age evidence for Paleoproterozoic sedimentation and 2.05 Ga syntectonic plutonism in the Nyong Group, South-Western Cameroon: Consequences for the Eburnean-Transamazonian belt of NE Brazil and Central Africa. J. Afr. Earth Sci. 2006, 44, 412-427. [CrossRef]

42. Neves, S.P.; Bruguier, O.; Vauchez, A.; Bosch, D.; Da Silva, R.M.J.; Mariano, G. Timing of crust formation, deposition of supracrustal sequences, and Transamazonian and Brasiliano metamorphism in the East Pernambuco belt (Borborema Province, NE Brazil): Implications for western Gondwana assembly. Precambrian Res. 2006, 149, 197-216. [CrossRef]

43. Okonkwo, T.C.; Ganev, Y.V. Geochemistry and geochronology of orthogneisses in Bode Saadu area, southwestern Nigeria and their implications for the Palaeoproterozoic evolution of the area. J. Afr. Earth Sci. 2015, 109, 131-142. [CrossRef]

44. Toteu, S.F.; Penaye, J.; Poudjom-Djomani, Y. Geodynamic evolution of the Pan-African belt in central Africa with special reference to Cameroon. J. Afr. Earth Sci. 2004, 41, 73-85. [CrossRef]

45. Abbelsalam, G.M.; Liégeois, P.J.; Stern, J.R. The Saharan Metacraton. J. Afr. Earth Sci. 2002, 34, 119-136. [CrossRef]

46. Ngako, V.; Njonfang, E.; Affaton, P. Pan-African tectonics in northwestern Cameroon: Implication for the history of the western Gondwana. Gondwana Res. 2008, 14, 509-522. [CrossRef]

47. Toteu, S.F.; Penaye, J.; Michard, A. New U-Pb and Sm-Nd data from North-Central Cameroon and its bearing on the prePanAfrican history of central Africa. Precambrian Res. 2001, 108, 45-73. [CrossRef]

48. Bouyo, H.M.; Zhao, Y.; Penaye, J.; Zhang, H.S.; Njel, O.U. Neoproterozoic subduction-related metavolcanic and metasedimentary rocks from the Rey Bouba Greenstone Belt of north-central Cameroon in the Central African Fold Belt: New insights into a continental arc geodynamic setting. Precambrian Res. 2015, 261, 40-53. [CrossRef]

49. Tchouankoué, P.J.; Tchaptchet, T.D.; Nyassa, M.L.; Njuinang, D.J.; Feudjou, M.C.; Tchato, F.C.; Ngambi, B.E.P.; Li, H.X. Evidence for a 2.06 Ga subduction at the western border of the Adamawa-Yade domain in Cameroon: Constraints from elemental geochemistry, zircon $\mathrm{Hf}$ isotopes and zircon $\mathrm{U} / \mathrm{Pb}$ geochronology from Ititin metabasites. J. Afr. Earth Sci. 2020, 175, 104001. [CrossRef]

50. Tchakounté, N.J.; Toteu, F.S.; Van Schmus, R.W.; Penaye, J.; Deloule, E.; Ondoua, M.J.; Houketchang, B.M.; Ganwa, A.A.; White, M.W. Evidence of ca 1.6 Ga detrital zircon in Bafia group (Cameroon): Implication for chronostratigraphy of the Pan-African Belt north of the Congo craton. Comptes Rendus Geosci. 2007, 339, 132-142. [CrossRef]

51. Tchameni, R.; Sun, F.; Dawaï, D.; Danra, G.; Tékoum, L.; Nomo Negue, E.; Vanderhaeghe, O.; Nzolang, C.; Nguihdama Dagwaï, N. Zircon dating and mineralogy of the Mokong Pan African magmatic epidote bearing granite (North Cameroon). Int. J. Earth Sci. 2016, 105, 1811-1830. [CrossRef]

52. Kwékam, M.; Talla, V.; Fozing, M.E.; Kouémo, J.T.; Dunkl, I.; Njonfang, E. The Pan-African high-K I-type granites from Batié Complex, West Cameroon: Age, origin, and tectonic implications. Front. Earth Sci. 2020, 8, 1-14. [CrossRef]

53. Nzenti, J.P.; Barbey, P.; Macaudiere, J.; Soba, D. Origin and evolution of the Late Precambrian high-grade Yaoundé gneisses (Cameroon). Precambrian Res. 1988, 38, 91-109. [CrossRef]

54. Njiosseu, T.L.E.; Nzenti, P.J.; Njanko, T.; Kapajika, B.; Nédélec, A. New U-Pb zircon ages from Tonga (Cameroon): Coexisting Eburnian-Transmazonian $(2.1 \mathrm{Ga})$ and Pan-African (0.6 Ga) imprints. Comptes Rendus Geosci. 2005, 337, 551-562. [CrossRef]

55. Fuh, C.G.; Nkoumbou, C.; Tchakounté, N.J.; Mukete, O.K.; Tchouankoué, P.J. Petrology, geochemistry, Ar-Ar isotopes of an arc related calk-alkaline pluton from Mamb (Pan-African Yaounde group, Cameroon): A testimony to the subduction of a hot oceanic crust. Lithos 2021, 384-385, 105973.

56. Tagne-Kamga, G. Petrogenesis of the Neoproterozoic Ngondo igneous plutonic complex (Cameroon, west central Africa): A case of late collisional ferro-potassic magmatism. J. Afr. Earth Sci. 2003, 36, 149-171. [CrossRef]

57. Kwékam, M.; Dunkl, I.; Fozing, M.E.; Hartmann, G.; Njanko, T.; Kouémo, J.T.; Njonfang, E. Syn-kinematic ferroan high-K I-type granites from Dschang in southwestern Cameroon: U-Pb age, geochemistry and implications for crustal growth in the late Pan-African orogeny. J. Geol. Soc. 2020, 502, 191-213. [CrossRef]

58. Tetsopgang, S.; Suzuki, K.; Adachi, M. Preliminary CHIME dating of granites from Nkambe area, northwestern Cameroon. J. Earth Planet. Sci. Nagoya Univ. 1999, 46, 57-70.

59. Tetsopgang, S.; Suzuki, K.; Njonfang, E. Petrology and CHIME geochronology of Pan-African high K and Sr/Y granitoids in the Nkambe area, Cameroon. Gondwana Res. 2008, 14, 686-699. [CrossRef]

60. Ganade de Araújo, C.E.; Rubatto, D.; Hermann, J.; Cordani, G.U.; Caby, R.; Basei, A.S.M. Ediacaran 2500-km-long synchronous deep continental subduction in the West Gondwana Orogen. Nat. Commun. 2014, 5, 1-8. [CrossRef]

61. Santos, E.J. Ensaio preliminar sobre terrenos e tectônica acrescionária na Província Borborema. In Congresso Brasileiro de Geologia; SBG Salvador: San Salvador, El Salvador, 1996; Volume 6, pp. 47-50.

62. Dantas, E.L.; De Souza, Z.S.; Wernick, E.; Hackspacher, P.; Martin, H. Crustal growth in the 3.4-2.7 Ga São José de Campestre Massif, Borborema Province, NE Brazil. Precambrian Res. 2013, 227, 120156. [CrossRef]

63. Ganade de Araújo, C.E.; Basei, M.; Grandjean, F.C.; Amstrong, R.; Brito, S.R. Contrasting Archaean (2.85-2.68 Ga) TTGs from the Tróia Massif (NE-Brazil) and their geodynamic implications for flat to steep subduction transition. Precambrian Res. 2017, 297, 1-18. [CrossRef] 
64. Pitarello, M.Z.; dos Santos, T.J.; Ancelmi, M.F. Syn-to post-depositional processes related to high grade metamorphic BIFs: Geochemical and geochronological evidences from a Paleo to Neoarchean (3.5-2.6 Ga) terrane in NE Brazil. J. S. Am. Earth Sci. 2019, 96, 102312. [CrossRef]

65. Caxito, A.F.; Santos, L.M.C.L.; Ganade, E.C.; Bendaoud, A.; Bouyo, H.M. Toward an integrated model of geological evolution for NE Brazil-NW Africa: The Borborema Province and its connections to the Trans-Saharan (Benino-Nigerian and Tuareg shields) and Central African orogens. Braz. J. Geol. 2020, 50, e20190122. [CrossRef]

66. Santos, F.G.; Neto, C.O.T.M.; Ferreira, V.P.; Bertotti, L.A. Eo to Paleoarchean metamafic-ultramafic rocks from the central portion of the Rio Grande do Norte Domain, Borborema Province, northeast Brazil: The oldest South American platform rock. J. S. Am. Earth Sci. 2020, 97, 102410. [CrossRef]

67. Sá, J.M.; McReath, I.; Leterrier, J. Petrology, geochemistry and geodynamic setting of Proterozoic igneous suites of the Orós fold belt (Borborema Province, Northeast Brazil). J. S. Am. Earth Sci. 1995, 8, 299-314. [CrossRef]

68. Sá, J.M.; Bertrand, J.M.; Leterrier, J.; Macedo, F.H.M. Geochemistry and geochronology of pre-Brasiliano rocks from the Transversal Zone, Borborema Province, Brazil. J. S. Am. Earth Sci. 2002, 14, 851-866. [CrossRef]

69. Lages, G.A.; Santos, L.C.M.L.; Brasilino, R.G.; Rodrigues, B.J.; Dantas, L.E. Statherian-Calymmian (ca. 1.6 Ga) magmatism in the Alto Moxotó Terrane, Borborema Province, northeast Brazil: Implications for withinplateand coeval collisional tectonics in West Gondwana. J. S. Am. Earth Sci. 2019, 91, 116-130. [CrossRef]

70. Oliveira, E.P.; Windley, B.F.; Araújo, M.N.C. The Neoproterozoic Sergipano orogenic belt, NE Brazil: A complete plate tectonic cycle in western Gondwana. Precambrian Res. 2010, 181, 64-84. [CrossRef]

71. Santos, E.J.; Van Schmus, W.R.; Kozuch, M.; Neves, B.B. The Cariris Velhos tectonic event in northeast Brazil. J. S. Am. Earth Sci. 2010, 29, 61-76. [CrossRef]

72. Caxito, F.A.; Uhlein, A.; Dantas, E.L. The Afeição augen-gneiss Suite and the record of the Cariris Velhos Orogeny (1000-960 Ma) within the Riacho do Pontal fold belt, NE Brazil. J. S. Am. Earth Sci. 2014, 51, 12-27. [CrossRef]

73. Caxito, A.F.; Basto, F.C.; Santos, L.M.C.L.; Dantas, L.E.; De Medeiros, C.V.; Dias, G.T.; Barrote, V.; Hagemann, S.; Alkmim, R.A.; Lana, C. Neoproterozoic magmatic arc volcanism in the Borborema Province, NE Brazil: Possible flare-ups and lulls and implications for western Gondwana assembly. Gondwana Res. 2020, 92, 1-25. [CrossRef]

74. Salgado, S.S.; Ferreira Filho, C.F.; Caxito, F.A.; Dantas, E.L.; Stevenson, R. The Ni-Cu-PGE mineralized Brejo Seco maficultramafic layered intrusion, RPO: Onset of Tonian (ca. 900 Ma) continental rifting in Northeast Brazil. J. S. Am. Earth Sci. 2016, 70, 324339. [CrossRef]

75. Caxito, F.A.; Uhlein, A.; Dantas, E.L.; Stevenson, R.; Salgado, S.S.; Dussin, A.I.; Sial, A.N. A complete Wilson Cycle recorded within the Riacho do Pontal Orogen, NE Brazil: Implications for the Neoproterozoic evolution of the Borborema Province at the heart of West Gondwana. Precambrian Res. 2016, 282, 97-120. [CrossRef]

76. Neves, S.P.; Lages, G.A.; Brasilino, R.G.; Miranda, A.W.A. Paleoproterozoic accretionary and collisional processes and the build-up of the Borborema Province (NE Brazil): Geochronological and geochemical evidence from the Central Domain. J. S. Am. Earth Sci. 2015, 58, 165-187. [CrossRef]

77. Bueno, J.F.; Oliveira, E.P.; McNaughton, N.; Laux, H.J. U-Pb dating of granites in the Neoproterozoic Sergipano Belt, NE-Brazil: Implications for the timing and duration of continental collision and extrusion tectonics in the Borborema Province. Gondwana Res. 2009, 15, 86-97. [CrossRef]

78. Van Schmus, W.R.; Kozuch, M.; Neves, B.B. Precambrian history of the Zona Transversal of the Borborema Province, NE Brazil: Insights from Sm-Nd and U-Pb geochronology. J. S. Am. Earth Sci. 2011, 31, 227-252. [CrossRef]

79. Neves, S.P.; Vauchez, A.; Archanjo, C.J. Shear-zone controlled magma emplacement or magma-assisted nucleation of shear zones? Insights from Northeast Brazil. Tectonophysics 1996, 262, 349-365. [CrossRef]

80. Weinberg, R.; Sial, A.N.; Mariano, G. Close spatial relationship between plutons and shear zones. Geol. J. 2004, 32, 377-380. [CrossRef]

81. Viegas, L.G.F.; Archanjo, C.J.; Hollanda, M.H.B.M.; Vauchez, A. Microfabrics and zircon U-Pb (SHRIMP) chronology of mylonites from the Patos shear zone (Borborema Province, NE Brazil). Precambrian Res. 2014, 243, 1-17. [CrossRef]

82. Miranda, S.T.; Neves, P.S.; Celestino, L.A.M.; Roberts, W.M.N. Structural evolution of the Cruzeiro do Nordeste shear zone (NE Brazil): Brasiliano-Pan-African- ductile-to-brittle transition and Cretaceous brittle reactivation. J. Struct. Geol. 2020, $141,104203$. [CrossRef]

83. Amaral, W.S.; Kraus, R.K.; Dantas, E.L.; Fuck, A.R.; Pitombeira, A.P.J. Sinistral reactivation of the Transbrasiliano Lineament: Structural and geochronological evidences in the Cariré Granulite Zone, Borborema Province-NE Brazil. J. S. Am. Earth Sci. 2017, 79, 409-420. [CrossRef]

84. Haruna, V.I. Review of the basement geology and mineral belts of Nigeria. IOSR J. Appl. Geol. Geophys. $2017,5,37-45$.

85. Haruna, V.I.; Mamman, D.Y. A brief review of some metallogenetic features of uranium mineralisation in the Upper Benue Trough, N.E. Nigeria. Technol. Dev. J. 2005, 9, 1-8.

86. McCurry, P. Pan-African orogeny in Northern Nigeria. Geol. Soc. Am. Bull. 1971, 82, 3251-3261. [CrossRef]

87. Benkhelil, J. Cretaceous deformation, magmatism, and metamorphism in the Lower Benue Trough, Nigeria. Geol. J. 1987, 22, 467-493. [CrossRef]

88. Maluski, H.; Coulon, C.; Popoff, M.; Baudin, P. ${ }^{40} \mathrm{Ar} /{ }^{39} \mathrm{Ar}$ chronology, petrology and geodynamic setting of Mesozoic to early Cenozoic magmatisim from the Benue Trough, Nigeria. J. Geol. Soc. 1995, 152, 311-326. [CrossRef] 
89. Ero, A.F.; Ekwueme, B.N. Mineralization of pegmatites in parts of the Oban Massif, Southeastern Nigeria: A preliminary analysis. Chin. J. Geochem. 2009, 28, 146-153. [CrossRef]

90. Ekwueme, B.N.; Schlag, C. Composition of monazites in pegmatites and related rocks of Oban Massif, SE Nigeria: Implications of Economic mineral exploration. IGCP Newsl. Bull. 1989, 2, 15-20.

91. Ekwueme, B.N. Structural orientations and Precambrian deformational episodes of Uwet area, Oban Massif, SE Nigeria. Precambrian Res. 1987, 34, 269-289. [CrossRef]

92. Ekwueme, B.N.; Caen-Vachette, M.; Onyeagocha, A.C. Rb-Sr geochronology of metasedimentary schists and gneisses in Uwet area, Oban massif, southeastern Nigeria. J. Min. Geol. 1988, 23, 119-124.

93. Njoh, O.A.; Nforsi, M.B.; Datcheu, J.N. Aptian-Late Cenomanian Fluvio-Lacustrine Lithofacies and Palynomorphs from Mamfe Basin, Southwest Cameroon, West Africa. Int. J. Geosci. 2015, 6, 795-811. [CrossRef]

94. Ajonina, N.H. Evolution of Cretaceous Sediments in the Mamfe Basin, SW Cameroon: Depositional Environments, Palynostratigraphy, and Paleogeography. Ph.D. Thesis, University of Hamburg, Hamburg, Germany, 2016.

95. Martin, E.J.; Menken, F.E.; Djomeni, A.; Fowe, G.P.; Ntamak-Nida, J.M. Dinosaur trackways from the early Late Cretaceous of 1 western Cameroon. J. Afr. Earth Sci. 2017, 134, 213-221. [CrossRef]

96. Reyment, R.A. Stratigraphy of the Southern Cameroon. Geol. For. Handl. Board 1954, 76, 661-683. [CrossRef]

97. Ajonina, H.N.; Ajibola, O.A.; Bassey, E.C. The Mamfé Basin, SE Nigeria and SW Cameroon: A review of the Basin filling model and tectonic evolution. J. Geosci. Soc. Cam. 2001, 1, 24-25.

98. Benkhelil, J. The origin and evolution of the Cretaceous Benue Trough (Nigeria). J. Afr. Earth Sci. 1989, 8, 251-282. [CrossRef]

99. Coulon, C.; Vidal, P.; Dupuy, C.; Baudin, P.; Popoff, M.; Maluski, H.; Hermitte, D. The Mesozoic to Early Cenozoic Magmatism of the Benue Trough (Nigeria); Geochemical Evidence for the Involvement of the St Helena Plume. J. Petrol. 1996, 37, 1341-1358. [CrossRef]

100. Ofoegbu, O.C.; Harcourt, P. A model for the tectonic evolution of the Benue Trough of Nigeria. Geol. Rundsch. 1984, 73, 1007-1018. [CrossRef]

101. Owona, S. Archean-Eburnean and Pan-African Features and Relationships in Their Junction Zone in the South of Yaoundé (Cameroon). Ph.D. Thesis, University Douala, Douala, Cameroon, 2008.

102. Olade, M.A. Evolution of Nigeria's Benue Trough (Aulacogen): A tectonic model. Geol. Mag. 1975, 112, 573-583. [CrossRef]

103. Ajonina, H.; Ajibola, O.A.; Bassey, C.E. A review of the sedimentology and reservoir quality of sandstones of the Mamfe Formation exposed in parts of southeastern Nigeria and southwestern Cameroon, Abstract. In 16th Annual International Conference and Exhibition; Nigerian Association Petroleum Exploration: Marina Lagos, Nigeria, 1998; p. 52.

104. Eseme, E.; Agyingi, M.C.; Foba-Tendo, J. Geochemistry and genesis of brine emanations from cretaceous strata of the Mamfe basin, Cameroon. J. Afr. Earth Sci. 2002, 35, 467-476. [CrossRef]

105. Ndougsa-Mbarga, T.; Manguelle-Dicoum, E.; Campos-Enriquez, J.O.; Yene Atangana, Q. Gravity anomalies, subsurface structures and oil and gas migration in Mamfe Cameron-Nigeria sedimentary basin. Geofisica Int. 2007, 46, 129-139.

106. Regnoult, J.M. Synthèse Géologique du Cameroun; Direction des Mines et de Géologie: Yaoundé, Cameroun, $1986 ;$ p. 119.

107. Ajonina, H.N.; Bassey, C.E. Stratigraphy and depositional environments of the Mamfe Formation and its implication on the tectono-sedimentary evolution of the Ikom-Mamfe embayment. In 15th Annual International Conference and Exhibition Book of Abstracts and Programme; Nigerian Association of the Petroleum Exploration (NAPE): Marina Lagos, Nigeria, 1997; 39p.

108. Eseme, E.; Littke, R.; Agyingi, M.C. Geochemical characterization of Cretaceous black shale from the Mamfe Basin, Cameroon. Petrol. Geosci. 2006, 12, 69-74. [CrossRef]

109. Eyong, T.J. Lithostratigraphy of the Mamfe Cretaceous Basin. South West Province of Cameroon-West Africa. Ph.D. Thesis, University of Leeds, Leeds, UK, 2003.

110. Eyong, T.J.; Wignall, P.; Fantong, Y.W.; Best, J.; Hell, J.V. Paragenetic sequences of carbonate and sulphide minerals of the Mamfe Basin (Cameroon): Indicators of palaeo-fluids, palaeo-oxygene levels and diagenetic zones. J. Afr. Earth Sci. 2013, 86, 25-44. [CrossRef]

111. Eyong, T.J.; Ngueutchoua, G.; Bessong, M.; Hell, J.V.; Bokanda, E.E.; Wignall, P.; Best, J. Sedimentologic and palaeoenvironmental evolution of the Mamfe Cretaceous Basin (SW Cameroon): Evidence from lithofacies analysis, tectonics and evaporite minerals suite. J. Afr. Earth Sci. 2019, 149, 19-41. [CrossRef]

112. Bokanda, E.E.; Philip, F.; Ekomane, E.; Njilah, I.K.; Bisse, S.B.; Akono, D.F.; Bessa, E.Z.A. Geochemical characteristics of shales in the Mamfe Basin, South West Cameroon: Implication for depositional environments and oxidation conditions. J. Afr. Earth Sci. 2018, 149, 131-142. [CrossRef]

113. Bokanda, E.E.; Ekomane, E.; Kenfack, N.G.R.; Njilah, I.K.; Ashukem, E.; Tematio, P.; Bisse, S.B.; Ngueutchoua, G.; Orock, N.S.; Belinga, B.C. Provenance, paleoclimate and diagenetic signatures of sandstones in the Mamfe Basin (West Africa). Heliyon 2018, 5 , e01140. [CrossRef]

114. Bokanda, E.E.; Ekomane, E.; Njilah, I.K.; Philip, F.; Bisse, S.B.; Ntoboh, C.T. Inorganic geochemistry and petroleum source evaluation of organic black shale in the Mamfe Basin (West Africa). Solid Earth Sci. 2019, 4, 166-177.

115. Ngueutchoua, G.; Eyong, T.J.; Bessa, E.Z.A.; Agheenwi, A.B.Z.; Maschouer, A.E.; Kemteu, S.C.; Dzoti, L.Y.; Hamadou, T.; Baboule, O.M.B.; Nguem, K.R.G. Provenance and depositional history of Mesozoic sediments from the Mamfe basin and Douala sub-basin (SW Cameroon) unraveled by geochemical analysis. J. Afr. Earth Sci. 2019, 158, 103550. [CrossRef] 
116. Njoh, O.A.; Njie, S.M. Hydrocarbon source rock potential of the lacustrine black shale unit, Mamfe Basin, Cameroon, West Africa. Earth Sci. Res. 2016, 6, 217-230.

117. Kanouo, S.N.; Zaw, K.; Yongue, F.R.; Sutherland, L.F.; Meffre, S.; Njonfang, E.; Ma, C. Detrital mineral morphology and geochemistry: Methods to characterize and constrain the origin of the Nsanaragati blue sapphires, south-western region of Cameroon. J. Afr. Earth Sci. 2012, 70, 18-23. [CrossRef]

118. Kanouo, S.N.; Ekomane, E.; Yongue, F.R.; Njonfang, E.; Zaw, K.; Ma, C.; Ghogomu, R.T.; Lentz, D.R.; Venkatesh, A.S. Trace elements in corundum, chrysoberyl, and zircon: Application to mineral exploration and provenance study of the western Mamfe gem clastic deposits (SW Cameroon, Central Africa). J. Afr. Earth Sci. 2016, 113, 35-50. [CrossRef]

119. Kanouo, S.N.; Yongue, F.R.; Ghogomu, R.T.; Njonfang, E.; Yomeun, B.S.; Basua, A.A.E. Petro-geochemistry, Genesis and Economic Aspects of Mafic Volcanic Rocks in the West and Southern Part of the Mamfe Basin (SW Cameroon, Central Africa). J. Geol. Geophys. 2017, 6, 298. [CrossRef]

120. Njonfang, E.; Moreau, C. The Mineralogy and geochemistry of a subvolcanic alkaline complex from the Cameroon line, the Nda Ali massif, South-West Cameroon. J. Afr. Earth Sci. 1996, 22, 113-132. [CrossRef]

121. Mcfarlane, M.R.C.; Luo, Y. U-Pb Geochronology using $193 \mathrm{~nm}$ Excimer LA-ICP-MS optimized for in situ accessory mineral dating in thin sections. Geosci. Can. 2012, 39, 158-172.

122. Halicz, L.; Erel, Y.; Vernon, A. Lead isotope ratio measurements by ICP-MS: Accuracy, precision, and longterm drift. At. Spectrosc. 1996, 7, 186-189.

123. Ludwig, K.R. Isoplot 3.00: A Geochronological Toolkit for Microsoft Excel. Berkeley Geochronol. Cent. Spec. Publ. $2003,4,70$.

124. Belousova, E.A.; Griffin, W.L.; Suzanne, Y.O. Zircon crystal morphology, trace element signatures and Hf isotopic composition as tool for petrogenetic modeling: Examples. J. Petrol. 2006, 47, 329-353. [CrossRef]

125. Nemchin, A.A.; Pidgeon, R.T. Evolution of the Darling Range batholith, Yilgarn Craton, Western Australia: A SHRIMP zircon study. J. Petrol. 1997, 38, 625-649. [CrossRef]

126. Schaltegger, U.; Gebauer, D.; Von Quadt, A. The mafic-ultramafic rock association of Loderio-Biasca (lower Pennine nappes, Ticino, Switzerland): Cambrian oceanic magmatism and its bearing on early Paleozoic paleogeography. Chem. Geol. 2002, 186, 265-279. [CrossRef]

127. Belousova, A.E.; Griffin, L.W.; Pearson, J.N. Trace element composition and cathodoluminesence properties of southern African kimberlitic zircons. Miner. Mag. 1998, 62, 355-366. [CrossRef]

128. Heaman, L.M.; Bowins, R.; Crocket, J. The chemical composition of igneous zircon suites: Implications for geochemical tracer studies. Geochem. Cosmochem. Acta 1990, 54, 1597-1607. [CrossRef]

129. Ahrens, L.H.; Cherry, R.D.; Erlank, A.J. Observations on the Th-U relationship in zircons from granitic rocks and from kimberlites. Geochim. Cosmochim. Acta 1967, 31, 2379-2387. [CrossRef]

130. Hoskin, P.W.O.; Black, L.P. Metamorphic zircon formation by solid-state recrystallization of protolith igneous zircon. J. Metamor. Geol. 2000, 18, 423-439. [CrossRef]

131. Kröner, A.; Rojas-Agramonte, Y.; Kehelpannala, K.V.W.; Zack, T.; Hegner, E.; Geng, Y.H.; Wong, J.; Barth, M. Age, Nd-Hf isotopes, and geochemistry of the Vijayan Complex of eastern and southern Sri Lanka: A Grenville-age magmatic arc of unknown derivation. Precambrian Res. 2013, 234, 288-321. [CrossRef]

132. Dada, S.S. Crust forming ages and Proterozoic crustal evolution in Nigeria: A reappraisal of current interpretations. Precambrian Res. 1998, 87, 65-74. [CrossRef]

133. Toteu, S.F.; Van Schmus, W.R.; Penaye, J.; Nyobé, J.B. U-Pb and Sm-Nd evidence for Eburnean and Pan-African high-grade metamorphism in cratonic rocks of southern Cameroon. Precambrian Res. 1994, 108, 45-73. [CrossRef]

134. Penaye, J.; Toteu, S.F.; Van Schmus, W.R.; Nzenti, P.J. U-Pb and Sm-Nd preliminary geochronologic data on the Yaoundé series, Cameroon: Reinterpretation of the granulitic rocks as the suture of a collision in the "Centrafrican belt". Comptes Rendus Acad. Sci. Paris 1993, 317, 789-794.

135. Nzenti, J.P. Prograde and retrograde garnet zoning at high pressure and temperature in metapelitic and grenatite rocks from Yaounde (Cameroon Pan-African north-equatorial fold belt). J. Afr. Earth Sci. 1992, 15, 73-79. [CrossRef]

136. Turner, C.D. Upper Proterozoic schist belts in the Nigerian sector of the Pan-African province of West Africa. Precambian Res. 1983, 21, 55-79. [CrossRef]

137. Rahaman, A.M.S.; Ekwere, S.J.; Azamatullah, M.; Ukpong, E.E. Petrology and geochemistry of granitic intrusive rocks from the western part of Oban Massif, SE Nigeria. J. Afr. Earth Sci. 1988, 7, 147-159.

138. Kröner, A.; Ekwueme, N.B.; Pidgeon, T.R. The oldest rocks in West Africa: SHRIMP zircon age for Early Archean migmatitic orthogneiss at Kaduna, Northern Nigeria. J. Geol. 2001, 109, 399-406. [CrossRef]

139. Grant, K.N. Geochronology of Precambrian basement rocks from Ibadan, southwestern Nigeria. Earth Plant. Sci. Lett. 1970, 10, 29-38. [CrossRef]

140. Kusky, T.M.; Abdelsalam, M.; Stern, R.J.; Tucker, R.; Stern, B. Evolution of the East African and related orogens, and the assembly of Gondwana. Precambrian Res. 2003, 123, 82-85. [CrossRef] 